Italian Journal of Geosciences

Bollettino della

Società Geologica Italiana

e del Servizio Geologico d'Italia

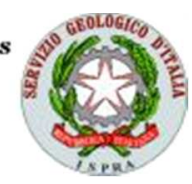

\title{
On the occurrence of the Neapolitan Yellow Tuff tephra in the Northern Phlegraean Fields offshore (Eastern Tyrrhenian margin; Italy)
}

\begin{tabular}{|r|l|}
\hline Journal: & Italian Journal of Geosciences \\
\hline Manuscript ID & IJG-2016-0558.R1 \\
\hline Manuscript Type: & Original Article \\
\hline Date Submitted by the Author: & n/a \\
\hline Complete List of Authors: & $\begin{array}{l}\text { Aiello, Gemma; National Research Council of Italy, Istituto per I'Ambiente } \\
\text { Marino Costiero } \\
\text { Insinga, Donatella; National Research Council of Italy, Istituto per } \\
\text { I'Ambiente Marino Costiero Naples, Italy, 80133, IT } \\
\text { Iorio, Marina; National Research Council of Italy, Istituto per I'Ambiente } \\
\text { Marino Costiero Naples, Italy, 80133, IT } \\
\text { Meo, Agostino; Universita degli Studi del Sannio, Dipartimento di Scienze e } \\
\text { Tecnologie } \\
\text { Senatore, Maria Rosaria; Università del Sannio, Dipartimento di Scienze e } \\
\text { Tecnologie }\end{array}$ \\
\hline Keywords: & $\begin{array}{l}\text { Phlegraean Fields, coastal volcanism, seismic stratigraphy, Neapolitan } \\
\text { Yellow Tuff, Gaeta Gulf }\end{array}$ \\
\hline
\end{tabular}


On the occurrence of the Neapolitan Yellow Tuff tephra in the Northern Phlegraean

Fields offshore (Eastern Tyrrhenian margin; Italy)

Sulla presenza del tefra del Tufo Giallo Napoletano nell'offshore settentrionale dei Campi Flegrei (margine tirrenico orientale, Italia).

Gemma Aiello (1*), Donatella Domenica Insinga (1), Marina Iorio (1) Agostino Meo (2) Maria Rosaria Senatore (2)

(1) Istituto per l'Ambiente Marino Costiero, Consiglio Nazionale delle Ricerche (CNR), Calata Porta di Massa, Porto di Napoli, 80133, Napoli, Italy

(2) Dipartimento di Scienze e Tecnologie, Università degli Studi del Sannio, CoNISMA, Benevento, Italy

(*) Corresponding Author

Gemma Aiello

Istituto per l'Ambiente Marino Costiero

Consiglio Nazionale delle Ricerche (CNR)

Calata Porta di Massa - Porto di Napoli

80133 - Napoli -Italy

Tel. 39-81-5423820 Fax: 39-81-5423888

Email: gemma.aiello@iamc.cnr.it 


\begin{abstract}
A main volcanic marker has been identified for the first time on the continental shelf of the northern Phlegraean Fields in the Gaeta Gulf (Campania region, eastern Tyrrhenian margin, Italy) by means of Subbottom Chirp profile grid and stratigraphic analysis of a core collected on the slope. In the seismic sections, the core bottom corresponds to the top of a continuous and parallel reflector $(V)$ interbedded within the transgressive deposits of the Late Quaternary-Holocene depositional sequence. The Transgressive System Tract deposits are particularly thick compared to the majority of the transgressive deposits of other shelf settings. This might be due to the input of pyroclastic and volcanoclastic deposits related to the intense eruptive activity of the Campania Plain during the Late Pleistocene-Holocene time span. Undulations and pockmarks are the main morphological features of the sea floor and they might be linked to gas uprising, widely detected in the study area. The $V$ reflector is located on the shelf from northeast to southwest at different depths, ranging from $10 \mathrm{~ms}$ (about $8 \mathrm{~m}$ ) to $30 \mathrm{~ms}$ (about $25 \mathrm{~m}$ ) below sea floor and it can be mapped down to the continental slope. The geological calibration of this continuous reflector coupled with tephrostratigraphic analysis, allowed to correlate it with the Neapolitan Yellow Tuff deposits emplaced at Phlegraean Fields at ca. $15 \mathrm{ka}$.
\end{abstract}

Key words: Neapolitan Yellow Tuff, Gaeta Gulf, Phlegraean Fields, coastal volcanism, seismic stratigraphy. 


\section{INTRODUCTION}

Coastal volcanism along the Campania margin plays a key role in the stratigraphic architecture of adjacent marine settings since it leads to several types of processes that supply large volumes of pyroclastic and volcanoclastic deposits over wide sectors of the continental shelf-slope-basin system during short time spans (INSINGA et alii, 2006; Milia et alii, 2007; DE Alteriss et alii, 2010, Budillon et alii, 2012). Pyroclastic deposits, in particular, are delivered to the sedimentary environment following a variety of transport processes such as fallout, flows and surges which can evolve across the continental shelf and slope in sediment failure or hyperpicnal flows (SACCHI et alii, 2005, 2009; MiLIA et alii, 2008). As a result of their synchronous deposition over large areas, pyroclastics (tephra) form important stratigraphic markers and event signals in the marine record (e.g. LOWE, 2011; ZANCHETTA et alii, 2011; INSINGA et alii, 2014 and references therein) and such findings are particularly frequent along the Campania margin in the Naples and Salerno gulfs and offshore Cilento (e.g.; BUCCHERI et alii, 2002; IORIO et alii, 2004; SACCHI et alii, 2005; INSINGA et alii, 2008; LIRER et alii, 2013; IORIO et alii, 2014a). A detailed geological literature exists on the structural and stratigraphic relationships between marine and volcanic units in the Gaeta Gulf since the Quaternary, however it is mainly based on seismic interpretations and onshore borehole data (Aiello et alii, 2000; Milia et alii, 2013; Torrente \& Milia, 2013; Milia \& Torrente, 2015). Core data regarding the marine stratigraphic record and the tephra deposits interbedded within are still very few and mainly related to the Holocene deposits (IORIO et alii, 2014b; MARGARITELLI et alii, 2016).

In this paper we report, for the first time, on the occurrence of the Neapolitan Yellow Tuff deposit in the southern sector of the Gaeta Gulf, between the Volturno mouth and the Cuma town, offshore the Northern Phlegraean Fields (Fig. 1). Based on gravity core data and high-resolution seismic profiles, the Neapolitan Yellow Tuff deposit was characterized both in terms of lithology and 
chemistry and its seismic signature was described and mapped. The obtained results aim to provide a contribution to the tephrostratigraphic framework of the southern Gaeta Gulf and highlight the significant role of this tephra in regards to the stratigraphic architecture of Northern Phlegraean offshore.

\section{GEOLOGIC SETTING}

The study area represents the seaward extension of the northern sector of the Campania Plain (Fig. 1), a coastal plain of southern Italy located along the Latium-Campania margin. This latter is characterized by Plio-Pleistocene tectonically-downthrown areas genetically related to normal and strike-slip faults linked to the geological evolution of the Eastern Tyrrhenian margin (“peri-tyrrhenian basins”; FABBRI et alii, 1981 BARTOLE et alii, 1984; MALINVERNO \& RYAN, 1986; MARIANi \& Prato, 1988; Florio et alii, 1999; BRUNo et alii, 2000; Aiello et alii, 2000, 2011a; 2011b; CASCIELLO et alii, 2006) and filled by coastal and marine deposits reaching thicknesses of several thousand of meters. In particular, in the Gaeta basin, extensional tectonics has been active along systems of ESE-WNW, E-W and NE-SW trending normal faults, related to strike-slip tectonic movements that took place mainly during the Late Pliocene-Early Pleistocene time interval (BARTOle et alii, 1984, Aiello et alii, 2000, BRUNO et alii, 2000).

The depositional geometries of strata pertaining to the Plio-Quaternary basin fill are similar to those recognized in the adjacent Terracina basin (AIELLO et alii, 2000). The lower seismic sequences are characterized by parallel horizons and are strongly affected by wedging and growth as a consequence of synsedimentary tectonics. The upper seismic sequences show progradational geometries led by sedimentary feeding from the Garigliano and Volturno rivers and controlled by eustatic sea-level fluctuations during Quaternary times (AIELLO et alii, 2000).

Regional geological evidence, coupled with seismo-stratigraphic interpretations, has suggested that the Volturno basin represents a half-graben structure, characterized by blocks downthrown along 
normal faults and filled by four main seismic units (identified as D1-D4; AIELLO et alii, 2011a; 2011b). Rapid flooding of coastal Volturno Plain culminated at 6.5 cal. ka B.P. (AMOROSI et alii, 2012 and references therein), leading to a narrowing of the shelf to a maximum width of $16 \mathrm{~km}$ in correspondence to Volturno river mouth and a minimum width in the Cuma offshore (about $10 \mathrm{~km}$ ). The shelf break occurs at water depths ranging between 120-125 m.

The stratigraphic architecture of the continental shelf during the Late Pleistocene - Holocene time interval is an incomplete $4^{\text {th }}$ order depositional sequence, that shows an inner strata organization with minor downlap surfaces and erosional truncations separating different phases of progradation (MARANi et alii, 1986; AIEllo et alii, 2000, 2011a; 2011b; IORIO et alii, 2014b). The last progradation started at about $130 \mathrm{ka}$ and ended at about $18 \mathrm{ka}$ (CATTANEO et alii, 2002; LOFI et alii, 2003; Duvail et alii, 2005; LisieCKI \& RAYMo, 2005; PELlEgrini et alii, 2010; CAPRARO et alii, 2011; MASELLI \& TRINCARDI, 2013; MASELLI et alii, 2014). An abrupt erosional surface separates the forced regression and lowstand deposits from the overlying sediments, that were formed between $18 \mathrm{ka}$ and $5 \mathrm{ka}$ during the last sea level rise (transgressive deposits; FABBRI et alii, 2002; CATtaneo \& Steel, 2003; TRINCARDi et alii, 1994) and from about 5 ka to present times during the recent sea level highstand (highstand deposits; HUNT \& TUCKER, 1992; COPPA et alii, 1996; BUCCHERI et alii, 2002). Since ca. $6.5 \mathrm{cal}$. ka, the highstand phase has marked the onset of the present-day Volturno delta and the progradation of the adjacent coastal plain, ranging between 3 and 6 km (BARra et alii, 1996; Bellotti, 2000; RomANo et alii, 2004; AMOrOSI et alii, 2012; SACCHI et alii, 2014b). Holocene wedge decreases in thickness towards the shelf edge. The continental slope is characterized by a uniform profile and is incised by several submarine gullies (Chiocci \& CASAlbore, 2011; Petruccione et alii, 2011). 


\subsection{The Neapolitan Yellow TufF}

Intense volcanism took place at several centers of the Campania Plain since at least the middle Pleistocene (DE VIVo et alii, 2001; RolANDI et alii, 2003; Di ViTo et alii, 2008; InsINGA et alii, 2014) as a consequence of the extensional tectonics that affected the eastern Tyrrhenian margin. During the Late Pleistocene, caldera-forming eruptions occurred inside the Campania Plain at Phlegraean Fields district with the most recent event of the Neapolitan Yellow Tuff (NYT) at $14.9 \pm 0.4 \mathrm{ka}$ (DEINO et alii, 2004). It erupted an estimated volume of about $45 \mathrm{~km}^{3} \mathrm{DRE}$ (Dense Rock Equivalent) covering an area of more than $1000 \mathrm{~km}^{2}$ and producing a caldera collapse of about $10 \mathrm{~km}$ in diameter (SCARPATI et alii, 1993; ORSI et alii, 1995). On the periphery of Phlegraean Fields and in the Campania Plain, the NYT exhibits high thickness and is characterized by a succession of pyroclastic fall and flow deposits (Lower and Upper Member, respectively; ORSI et alii, 1992, 1995). The Lower Member is compositionally bimodal (trachytic and trachyphonolitic) whereas the Upper Member spans the full compositional range between the two Lower Member populations (TOMLINSON et alii, 2012). Distal ash-fall deposits spread over wide areas up to northern Europe in marine and continental archives (e.g. PATERNE et alii, 1986; CALANCHI et alii, 1998; SIANI et alii, 2004; BouRne et alii, 2010; LANE et alii, 2015 and references therein). By contrast, far from the vent on land, such as in the Volturno coastal plain, the NYT is absent due to the removal-burial by fluvial processes (AMOROSI et alii, 2012). The NYT products had a strong impact on the sedimentary processes and, ultimately, on the stratigraphic record of adjacent marine settings, as documented in the Pozzuoli Bay (AIELLO et alii; 2012; SACCHI et alii, 2014a; AIELlO et alii, in press.)

\section{DATASET AND METHODS}




\subsection{GRAVITY CORE C1161}

The core C1161 was recovered at $144 \mathrm{~m}$ below the sea level on the right side of an upper slope gully in the northern sector of Phlegraean Fields offshore (Fig. 1) using a $6 \mathrm{~m}$ long gravity corer with liners of $9 \mathrm{~cm}$ in diameter. Core recovery was about $50 \%$ with an estimated compaction of about $15 \%$. The stratigraphic record consists of ca. 2.62 m-thick Holocene deposits which have been studied in detail with respect to their lithological, sedimentological, petrophysical and seismic aspects (IORIO et alii, 2014b). The sediments are mainly represented by silty and clayey deposits. A grain-size variation occurs at about $1.60 \mathrm{~m}$ below sea floor down to the core bottom, where sandy and gravelly fractions, mainly made up of bioclastic and pumiceous clasts, occur. Sedimentological analysis suggested a high energy depositional environment (IORIO et alii, 2014b), in agreement with the location of the core on a submarine channel levee. The integrated petrophysical (high magnetic susceptibility values) and seismic analysis correlated the bottom of the core to the top of a seismic reflector interpreted as being of volcanic origin ( $V$ in IORIO et alii, 2014b). The sediment was sampled and chemically analysed for the purposes of this work.

\subsubsection{TEPHRA ANALYSIS}

The non visible-tephra (cryptotephra) found at the core bottom and corresponding to the top of the reflector $V$ in IORIO et alii (2014b), was sampled, disaggregated in distilled water and wet sieved at 63, 90, 125 and $250 \mu \mathrm{m}$ in order to remove the fine-grained sediment. The sieved material was cleaned with an ultrasonic probe, dried at $60^{\circ} \mathrm{C}$ and then it was observed at the optical microscope in order to describe the lithology and to pick up fresh glasses for the chemical characterization. At least 25 juvenile fragments (pumiceous and glass shards) were mounted on epoxy resin and suitably polished for microprobe analysis.

Energy Dispersive Spectrometric (EDS) analyses were performed using JEOL JSM-5310 SEM at CISAG (Centro Interdipartimentale di Servizio per Analisi Geomineralogiche) of the University of 7 
Napoli "Federico II" through Oxford Instruments Microanalysis Unit, equipped with an INCA Xact detector. The operating conditions were $15 \mathrm{kV}$ primary beam voltage, $50-100 \mathrm{~m}$. A filament current, $50 \mathrm{sec}$ acquisition time with variable spot size was adopted during the data elaboration. A correction for matrix effect was performed using INCA version 4.08 software that used the XPP correction routine, based on a Phi-Ro-Zeta approach. Moreover, a primary calibration was performed using international mineral and glass standards USMN reference samples according to the following scheme: Anorthoclase 133868 for $\mathrm{Si}$ and $\mathrm{Na}$, Microcline 143966 for $\mathrm{Al}$ and $\mathrm{K}$, Fayalite 85276 for Mn, Anorthite 137041 for Ca, Hornblende 143965 for Fe, Mg and Ti, Scapolite 6600-1 for Cl, and Apatite 104021 for P.

Precision and accuracy were assessed using the rhyolitic glass USMN 75854 as secondary standard. Mean precision was $<5 \%$ for $\mathrm{SiO}_{2}, \mathrm{Al}_{2} \mathrm{O}_{3}, \mathrm{~K}_{2} \mathrm{O}, \mathrm{CaO}$ and $\mathrm{FeO}$, and around $10 \%$ for the other elements.

\subsection{SEISMIC DATA ACQUISITION}

Six Chirp profiles, collected in the frame of research projects on marine geological mapping on the continental shelf off the Campania region (penetration between 25 and $50 \mathrm{~m}$ below the sea bottom using an average velocity of $1.550 \mathrm{~m} / \mathrm{sec}$ for time-to-depth conversion), provided the stratigraphic framework to recognize the volcanic marker (Tab. 1). High resolution seismic stratigraphy has been described in detail as a valuable technique of analysis of seismic profiles (MITCHUM et alii, 1977; VAIL et alii, 1977; VAN WAGONER et alii, 1988; CATUNEANU et alii, 2009; ZECCHIN \& CATUNEANU, 2013) and has been herein applied in the geological interpretation of seismic profiles. Positioning was established through the Starfix differential GPS. The software IHS Kingdom ${ }^{\circledR}$ was used for the processing, management and interpretation of the seismic lines. The seismostratigraphic results were integrated with stratigraphic results previously obtained on the same dataset (PETRUCCIONE et alii, 2011; IORIO et alii, 2014b) and with new data from core samples 
(tephrostratigraphy)

\section{RESULTS}

\subsection{TEPHROSTRATIGRAPHY}

The analyzed cryptotephra, here labelled as C1161/1, is represented by medium- to fine-grained ash made up of light grey elongated pumices, light-grey glass shards with fibrous and bubble wall junction morphologies and brown blocky glass shards. Loose crystals of feldspar, biotite and clinopyroxene occur in the deposit along with rare lithics and bioclasts. According to the TAS (Total Alkali/Silica; LE MAITRE, 2005) classification diagram, glasses from C1161/1 straddle the trachyte/phonolite (hence being trachyphonolites) and the tephriphonolite/latite boundary forming a continuum of compositions (Fig. 3a). A few points fall within the trachyte and phonolite fields. The silica values range from 54.90 wt. $\%$ to 62.90 wt.\%, $\mathrm{CaO}$ and $\mathrm{FeO}_{\text {tot }}$ from 1.70 wt.\% to 5.55 wt.\% and from $2.50 \mathrm{wt} . \%$ to $6.66 \mathrm{wt} . \%$ respectively, $\mathrm{MgO}$ from $0.27 \mathrm{wt} \%$ to $2.36 \mathrm{wt} \%$ whereas $\mathrm{Al}_{2} \mathrm{O}_{3}$ is approximately constant. The alkali content ranges from $10.78 \mathrm{wt} \%$ to $14.20 \mathrm{wt} . \%$ (Tab. 2).

\subsection{HIGH RESOLUTION SEISMIC STRATIGRAPHY}

The seismo-stratigraphic interpretation of six Chirp seismic profiles, significant for the stratigraphic architecture of the northern Phlegraean offshore (Tab.1), has been carried out in order to map the trend of the seismic horizon $V$.

The oldest seismic unit is represented by the Falling Stage System Tract (FSST; Figs. 4, 5 and 6). It is characterized by seismic reflectors in offlap, grading seawards into a wedge-shaped seismic unit, interpreted as the Shelf Margin System Tract (SMST). Due to the limited penetration of the seismic sections, the FSST and the SMST are not well detectable. In the M198 seismic profile (Fig. 5), the SMST has not been recognized, because the present-day shelf break is shallower than the one 9 
corresponding to the last phase of sea level lowstand (120 m bsl; CHAPPELL AND SHACKLETON, 1986; LAMBECK AND CHAPPELL, 2001; LAMBECK et alii, 2014). In the M196 seismic profile, the FSST and the SMST are bounded upwards by the transgressive surface (T), marking the first major flooding of the continental shelf following the lowstand phase (Fig. 5). In this case the transgressive surface coincides with the 4 th order sequence boundary. The transgressive paralic deposits have been observed mainly on NW-SE trending seismic profiles and they are characterised by variable thickness (Fig. 4). They rest in downlap on the $\mathrm{T}$ surface and are separated from the overlying marine deposits by the ravinement surface (RS). Both the transgressive surface (T) and the ravinement surface (RS) appear as marked irregular erosional surfaces, gently deepening seawards (Figs. 4, 5 and 6). The FSST has been interpreted as Upper Pleistocene prograding deposits and it is overlaid by a very thick Transgressive System Tract (TST). The TST marine deposits onlap onto the RS (Figs. 4 and 5). They are characterized by parallel and continuous seismic reflectors with moderate to low amplitude. The TST upper boundary is the maximum flooding surface (MFS), which is often interrupted by shallow gas pockets (Figs. 4, 5 and 6). Above the MFS surface, the Highstand System Tract (HST) is represented by a wedge-shaped seismic unit thickening landwards. It is distinguished by discontinuous seismic reflectors with a moderate high amplitude.

The $V$ reflector is parallel and displays a high amplitude. It has been continuously detected from the shelf to the slope within the transgressive marine deposits (Figs. 4, 5 and 6). On the inner shelf its continuity is interrupted by shallow gas pockets. The $V$ depths ranges from $2 \mathrm{~ms}$ bsf on the slope to $28 \mathrm{~ms}$ bsf on south-eastern sector of the continental shelf. The overlying TST and HST deposits are affected by undulations, often downthrown by small-scale normal faults having a limited offset (IORIO et alii, 2014b). Undulations mainly occur in the outer shelf controlling the thickening of sediments. 


\section{DISCUSSION}

\subsection{TEPHRA CORRELATION}

The major element features of cryptotephra C1161/1 are typical of mildly silica undersaturated to saturated potassic products of Phlegraean activity occurred during the Late Pleistocene-Holocene time interval (SMITH et alii, 2011; TOMLINSON et alii, 2012). The wide chemical composition ranging from trachyphonolites to less evolved portions and the finding of the tephra within the transgressive marine deposits, indicate the correlation of C1161/1 to the NYT products dated via the ${ }^{40} \mathrm{Ar} /{ }^{39} \mathrm{Ar}$ method at $14.09 \pm 0.4 \mathrm{ka}$ (DEINO et alii, 2004) and later refined to $14.11 \pm 0.21$ cal. ka B.P. (BLOCKLEY et alii., 2008). In detail, chemistry of our tephra is well within the NYT-Upper Member population but a contribution of the Lower Member cannot be discarded (Fig. 3a-b-c). The NYT has been correlated to marine tephra C-2 up to $250 \mathrm{~km}$ from the Phlegraean Fields in the Tyrrhenian and Adriatic seas and it likely records both the Lower and Upper Member composition (e.g. PATERnE et alii., 1986; CALANCHI et alii., 1998; SIANI et alii, 2004, BOURNE et alii, 2010; MORABITO et alii, 2014). At very distal sites in northern Europe, the NYT tephra records only the bi-modal Lower Member (LANE et alii, 2015 and references therein). However, in the Tyrrhenian and Adriatic seas the correlation is not straightforward since a number of tephras with strong chemical similarity to the NYT immediately underlies tephra C-2 (SIANI et alii, 2004; BOURNE et alii, 2010; MORABITO et alii, 2014). This tephra framework may be the result of a complex stratigraphy on land that led some authors to propose different hypotheses about the origin of the NYT deposits: 1) they were emitted at different times from different eruptive centers (e.g. Rosi \& SBRANA, 1987); 2) they were the result of a single event on land perhaps from multiple vents (e.g. ORSI et alii, 1992, 1995, SCARPATI et alii, 1993). According to data from the southern Adriatic, SIANI et alii (2004) suggested that the NYT could represent the last event of a series of eruptions closely spaced in time (ca. 600 years), thus aiming to solve the volcanological issue. This might be in agreement with our finding of the NYT tephra at the top of the $V$ main volcanic reflector. It is 
possible, in fact, that the $V$ marker correlates with other pyroclastic and volcanoclastic deposits from eruptions closely spaced in time to the NYT and immediately underlying it. However, the need to improve the stratigraphic analysis of the whole $V$ reflector at other sites of the Gulf is required to confirm or deny the above hypothesis.

\subsection{Stratigraphy and $V /$ NYT marker}

The seismostratigraphic data obtained from the measurements of depths allowed to construct sketch diagrams which show the pattern of the NYT tephra in relation with the depth calculated from both the sea level and the sea floor (Figs. 7 and 8, respectively). Three-dimensional views of the NYT/seismic reflector are also reported (insets in Figs. 7 and 8).

The depth pattern of the NYT seismic reflector measured from the sea level depicts a surface regularly dipping towards south-west, proceeding from the shelf to the basin (Fig. 7). The thickness of sediments overlying the NYT deposits is very high on the shelf (Fig 8) and, in detail, ranges from $10 \mathrm{~ms}$ (about $8 \mathrm{~m}$ ) to $30 \mathrm{~ms}$ (about $25 \mathrm{~m}$ ) (Fig. 8). Greater depths, between $26 \mathrm{~ms}$ and $30 \mathrm{~ms}$ are reached along a NE-SW trending area located in the central part of the shelf where sediment undulations, gas charged sediments, and pockmarks, identified in Iorio et alii ( $2014 \mathrm{~b}$ ), have been mapped (Fig. 8). These features are typical of other examples where undulated reflectors characterize thick prodelta wedges on the Mediterranean shelves (e.g., TRINCARDI \& NORMARK 1988; CORREgGIARI et alii, 2001; LyKOUSIS et alii, 2003). The origin of undulations in the study area has been largely debated in Iorio et alii (2014b). The authors related them mainly to sheardominated failure with limited downslope displacement rather than erosional/depositional processes. The displacement was likely favored by high sediment supply, high-water content, fluid escapes and shelf gradient deepening. 
In this study case, the seismic facies related to undulations are discontinuous, probably due to frequent occurrence of gas within the sediments (ERCILLA et alii, 1994, 1995; CORREGGIARI et alii, 2001). In fact, in correspondence of each undulation we can observe, on the seismic profiles, the typical transparent seismic facies correlated to the presence of gas (Figs. 4, 5 and 6).

The NYT is interlayered in the TST marine deposits (Figs. 4, 5 and 6) which are particularly developed in this area compared to the majority of TST deposits on the continental shelves of other settings (TrincARdi et alii, 1994; CATTANeO \& Steel, 2003; MARTORELli et alii, 2010; Pellegrini et alii, 2010; Zecchin \& CAtuneanu, 2013), such as in the Salerno Gulf where the TST is characterized by a thin succession of sediments in spite of active fluvial supply during that time span (BUCCHERI et alii, 2002). However, in the Naples Gulf the TST is difficult to be defined in terms of thickness and distribution due to the complex interplay among volcanism, tectonics and sedimentary processes (e.g. MILIA, 1998a). So far, the high thickness of the TST deposits in the study area, which reaches the maximum value of about $40 \mathrm{~ms}(30 \mathrm{~m})$, might be related to the input of large amounts of pyroclastic and volcanoclastic materials associated to the NYT eruption and to the subsequent eruptive periods of the Phlegraean Fields (DI VITO et alii, 1999) before the deposition of the HST deposits (from ca. 6.5 cal ka B.P.; AMOROSI et alii, 2012). In particular, volcanoclastic deposits were delivered to the shelf and slope by the fluvial erosion, transportation and depositional system of the Volturno coastal plain where the NYT is found only in correspondence to the morpho-structural highs (AMOROSI et alii, 2012, SACCHI et alii, 2014b). The HST deposits are quite thin if compared with the HST deposits of the adjacent Pozzuoli and Naples gulfs where the active volcanic vents located along the coastline continuously acted as significant sediment sources (pyroclastic, volcanoclastic and epiclastic) to the marine depositional system (e.g. MiLIA, 1998b; AIELLO et alii, 2001; SACCHI et alii, 2005) irrespective of the size of the eruption.

\section{CONCLUSION}


Core data and seismic profiles allowed to recognize and map for the first time the NYT deposits in southern Gaeta Gulf. The data presented in this work point to a relevant role that the NYT deposition had on the stratigraphic architecture and morphological evolution of the study area. According to its wide distribution, it can be considered an excellent marker horizon for the basin and, hence, used as a tool for future stratigraphic, volcanological and marine hazard studies. The NYT is interbedded within the TST succession which has a considerable thickness likely due to the supply of pyroclastic and volcanoclastic deposits related to the intense eruptive activity from the close volcanoes during the Late Pleistocene-Holocene. Undulations and pockmarks are the main morphological features at the sea floor in the study area and they might be mainly related to the intense gas uprising through the TST and HST deposits. The presented results are part of a wider study which currently focuses on the Upper Pleistocene-Holocene evolution of the overall Gaeta Gulf, a pery-Tyrrhenian basin located at mid-position from the Campania Plain eruptive vents.

\section{ACKNOWLEDGMENTS}

The authors wish to thank Roberto Dè Gennaro for his assistance during SEM-EDS acquisition. Biagio Giaccio, Gianni Zanchetta and Roberto Sulpizio are greatly acknowledged for their comments and suggestions that greatly improved the manuscript. This research benefited of grants to M.R.S. from FRA Projects (Sannio University). 


\section{REFERENCES}

Aiello G., Marsella E., SACCHI M. (2000) Quaternary structural evolution of the Terracina and Gaeta basins (Eastern Tyrrhenian margin, Italy). Rend. Lincei, 11, 41-58.

Aiello G., Budillon F., Cristofalo G., D’Argenio B., De Alteris G., De lauro M., Ferraro L., Marsella E., Pelosi N., Sacchi M., Tonielli R. (2001) Marine geology and morphobathymetry in the Bay of Naples (South-Eastern Tyrrhenian sea, Italy). In: FARANDA F.M., Guglielmo L., Spezie G. (Eds.) Structures and Processes of the Mediterranean Ecosystems. Springer-Verlag, Milano, Italy, pp. 1-8.

Aiello G., Cicchella A.G., Di Fiore V., Marsella E.(2011a) New seismo-stratigraphic data of the Volturno Basin (northern Campania, Tyrrhenian margin, southern Italy): implications for tectono-stratigraphy of the Campania and Latium sedimentary basins. Ann. Geophys., 54 (3), 265283.

Aiello G., Marsella E., Cicchella A.G., Di Fiore V. (2011b) New insights on morphostructures and seismic stratigraphy along the Campania continental margin (Southern Italy) based on deep multichannel seismic profiles. Rend. Lincei, 22, 349-373.

Aiello G., Marsella E., Di Fiore V. (2012) New seismo-stratigraphic and marine magnetic data of the Gulf of Pozzuoli (Naples Bay, Tyrrhenian sea, Italy): inferences for the tectonic and magmatic events of the Phlegrean Fields volcanic complex (Campania). Mar. Geophys. Res., 33 (2), 93-125.

Aiello G., Giordano L., GiORDANO F. (2016) High resolution seismic stratigraphy of the Gulf of Pozzuoli (Naples Bay) and relationships with submarine volcanic setting of the Phlegrean Fields volcanic complex. Rend. Lincei, accepted article in press., doi: 10.1007/s12210-016-0573-z.

Amorosi A., PAcifico A., Rossi V., RUBerti D. (2012) Late Quaternary incision and deposition in an active volcanic setting: the Volturno valley fill, southern Italy. Sed. Geol., 282, 307-320.

Barra D., Romano P., Santo A., Campajola L., Roca V., Tuniz C. (1996) The versilian transgression in the Volturno river plain (Campania, southern Italy): paleoenvironmental history and chronological data. Il Quaternario, 9, 445-458.

Bartole R., Savelli C., Tramontana M., Wezel F.C.(1983) Structural and sedimentary features in the Tyrrhenian margin off Campania, southern Italy. Mar. Geol., 55, 163-180.

Bellotti P. (2000) Il modello morfosedimentario dei maggiori delta tirrenici italiani. Boll. Soc. Geol. It., 119, 777-792.

Bigi G., Cosentino D., Parotto M., Sartori R., Scandone P. (1992) Structural Model of Italy Scale 1:500.000. C.N.R., Progetto Finalizzato Geodinamica, Italy.

Bigi S., Doglioni C., Mariotti G. (2002) Thrust vs normal fault decollements in the Central Apennines. Boll. Soc. Geol. It., Volume Speciale n. 1, 161-166.

Blockley, S.P.E., RAMSEY, C.B., PYLE, D.M. (2008) Improved age modelling and high-precision age estimates of late Quaternary tephras, for accurate palaeoclimate reconstruction. J. Volcanol. Geotherm. Res., 177 (1), 251-262. 
Bonardi G., Amore F.O., Ciampo G., De Capoa P., Miconnet P., Perrone V. (1992) Il Complesso Liguride Auct: stato delle conoscenze e problemi aperti sull'evoluzione preappenninica ed i suoi rapporti con l'Arco Calabro. Mem. Soc. Geol. It., 41, 17-35.

Bourne, A.J., Lowe, J.J., TrincArdi, F., Asioli, A., Blockley, S.P.E., Wulf, S., MATthews, I.P., PIVA, A., VigliotTI, L. (2010) Distal tephra record for the last ca 105,000 years from core PRAD 1-2 in the central Adriatic Sea: implications for marine tephrostratigraphy. Quat. Sci. Rev. 29, 3079-3094.

Bruno P.P., Di Fiore V., Ventura G. (2000) Seismic study of the 41st Parallel Fault System offshore the Campanian-Latial continental margin, Italy. Tectonophysics, 324, 37-55.

Buccheri G., Capretto G., Di Donato V., Esposito P., Ferruzza G., Pescatore T., Russo Ermolli E., Senatore M.R., Sprovieri M., Bertoldo M., Carella D., Madonia G. (2002) $A$ high resolution record of the last deglaciation in the southern Tyrrhenian sea: environmental and climatic evolution. Mar. Geol., 186, 447-470.

Budillon F., Senatore M.R., Insinga D.D., Iorio M., Lubritto C., Roca M., Rumolo P. (2012) Late Holocene sedimentary changes in shallow water settings: the case of the Sele river offshore in the Salerno Gulf (south-eastern Tyrrhenian Sea, Italy). Rendi. Lincei, 23 (1), 25-43.

Calanchi, N., Cattaneo, A., Dinelli, E., Gasparotto, G., Lucchini F. (1998) Tephra layers in Late Quaternary sediments of the central Adriatic Sea. Mar. Geol. 149, 191-209.

Capraro L., Massari F., Rio D., Fornaciari E., Backman J., Channell J.E.T., Macrì P., Prosser G., Speranza F. (2011) Chronology of the Lower-Middle Pleistocene succession of the south-western part of the Crotone Basin (Calabria, Southern Italy). Quat. Sci. Rev. 30, 1185-1200

Casciello E., Cesarano M., Pappone G. (2006) Extensional detachment faulting on the Tyrrhenian margin of the southern Apennines contractional belt, (Italy). J. Geol. Soc., 163, 617629.

CAtTAneo A., Correggiari A., TRInCARdi F. (2002) Recognition of turbidite elements in the lateQuaternary Adriatic basin: where are they and what do they tell us? Mediterranean and Black sea Turbidite Systems and Deep Sea Fans. Bucharest 5-8, June 2002.

Cattaneo A.\& Steel R.J. (2003) Transgressive deposits: a review of their variability. Earth Sci. Rev., 62, 187-228.

Catuneanu O., Abreu V., Bhattacharya J.P., Blum M.D., Darlymple R.W., Eriksson P.G., Fielding C.R., Fisher W.I., Galloway W.E., Gibling M.R., Giles K.A., Holbrook J.M., Jordan R., Kendall C.G. St., Macurda B., Martinsen O.J., Miall A.D., Neal J.E., Nummendal D., Pomar L., Posamentier H.W., Pratt B.R., Sarg J.F., Shanley K.W., Steel R.J., Strasser A., TUCKer M.E., WINKER C. (2009) Towards the standardization of sequence stratigraphy. Earth Sci. Rev., 92, 1-33.

Chappell J. \& Shackleton N.J. (1986) Oxygen isotopes and sea level. Nature, 324, 137-140.

ChIOCCI F.L. \& CASAlBore D. (2011) Submarine gullies on Italian upper slopes and their relationship with volcanic activity revisited 20 years after Bill Normark's pioneering work. Geosphere, 7 (6), 1284-1293.

Cinque A., Irollo G., Romano P., Ruello M.R., Amato L., Giampaola D. (2011) Ground movements and sea level changes in urban areas: 5000 years of geological and archeological record from Naples (southern Italy). Quat. Int., 232, 45-55.

16 
Coppa M.G., Ferraro L., Pennetta M., Russo B., Valente A., Vecchione C. (1996) Sedimentology and micropaleontology of the core G39-C27 (Gaeta bay, central Tyrrhenian Sea, Italy). Il Quaternario, 9 (2), 687-696.

Correggiari A., Trincardi F., Langone L., Roveri M. (2001) Styles of failure in late holocene highstand prodelta wedges on the adriatic shelf. J. Sedim. Res. 71(2), 218-236. doi:10.1306/042800710218

De AlteriIs G., Insinga D.D., Morabito S., Morra V., Chiocci F.L., Terrasi F., Lubritto C., Di Benedetto C., PAZzANESE M. (2010) Age of submarine debris avalanches and tephrostratigraphy offshore Ischia island, Tyrrhenian sea, Italy. Mar. Geol., 278, 1-18.

Deino A.L., Orsi G., Piochi M., De Vita S. (2004) The age of the Neapolitan Yellow Tuff calderaforming eruption (Campi Flegrei caldera - Italy) assessed by 40Ar/39Ar dating method. J. Volcanol. and Geotherm. Res., 133, 157-170.

De Vivo B., Rolandi G., Gans P.B., Calvert A., Bohrson W.A., Spera F.J., Belkin H.E. (2001) New constraints on the pyroclastic eruptive history of the Campanian volcanic plain (Italy). Mineral. Petrol., 73, 47-65.

Di Vito M.A., Isaia R., Orsi G., Southon J., De Vita S., D’Antonio M., Pappalardo L., Piochi M. (1999) Volcanism and deformation since 12.000 years at the Campi Flegrei caldera (Italy). J. Volcanol. and Geotherm. Res., 91, 221-246.

Di Vito, M., Sulpizio, R., Zanchetta, R., D’Orazio, M. (2008) The late Pleistocene pyroclastic deposits of the Campanian Plain: new insights on the explosive activity of Neapolitan volcanoes. J. Volcanol. Geotherm. Res. 177, 19-48.

Duvail C., Gorinib C., Lofi J., Le Strata P., Clauzond G., Dos Reise A.T. (2005) Correlation between onshore and offshore Pliocene-Quaternary systems tracts below the Roussillon Basin (eastern Pyrenees, France). Mar. Petrol. Geol., 22, 747-756.

ERcilla G., Alonso B., BARAZA J. (1994) Post-calabrian sequence stratigraphy of the northwestern Alboran Sea (southwestern Mediterranean). Mar. Geol. 120 (3-4), 249-265. doi:10.1016/ 0025-3227(94)90061-2

ERcilla G., DìAz J.I., Alonso B., FARRAn M. (1995) Late pleistocene- holocene sedimentary evolution of the northern Catalonia continental shelf (northwestern Mediterranean Sea). Cont. Shelf. Res. 15(11-12), 1435-1451. doi:10.1016/0278-4343(94)00089-6

FabBri A., Gallignani P., Zitellini N. (1981) Geological evolution of the perityrrhenian sedimentary basins. In: WEZEL F.C. (Ed.) Sedimentary basins of the Mediterranean margins. Tecnoprint, Bologna, Italy.

Fabbri A., Argnani A., Bortoluzzi G., Correggiari A., Gamberi F., Ligi M., Marani M., PEnItenti D., Roveri M., TRINCARDI F. (2002) Linee guida al rilevamento geologico dei mari italiani. Pres. Cons. Min., Quaderno 8.

Florio G., Fedi M., Cella F., Rapolla A. (1999) The Campanian Plain and Phlegrean Fields: structural setting from potential field data. J. Volcanol. Geotherm. Res., 91 (2/4), 361-379.

HunT D. \& TUCKER M.E. (1992) Stranded parasequences and the forced regressive wedge system tract deposition during base-level-fall. Sediment. Geol., 81, 1-9. 
Insinga D.D., Molisso F., Lubritto C., SACChi M., Passariello L., Morra V. (2008) The proximal marine record of Somma-Vesuvius volcanic activity in the Naples and Salerno bays, Eastern Tyrrhenian sea, during the last 3 kyrs. J. Volcanol. Geoth. Res., 177, 170-186.

Insinga D.D., Tamburrino S., Lirer F., Vezzoli L., Barra M., De Lange G.J., Tiepolo M., VAllefuoco M., Mazzola S., Sprovieri M. (2014) Tephrochronology of the astronomicallytuned KC01B deep-sea core, Ionian Sea: insights into the explosive activity of the Central Mediterranean area during the last $200 \mathrm{ka}$. Quat. Sc. Rev., 85, 63-84.

Iorio M., Sagnotti L., Angelino A., Budillon F., D’Argenio B., Dinares-Turell J., Macrì P., MARSELla E. (2004) High resolution petrophysical and palaeomagnetic study of Late Holocene shelf sediments, Salerno Gulf, Tyrrhenian Sea. The Holocene, 14 (3), 426-425.

Iorio M., Liddicoat J., Budillon F., Incoronato A., Coe R.S., Insinga D.D., Cassata W., Lubritto C., ANGelino A., TAMBurRino S. (2014a) Combined palaeomagnetic secular variation and petrophysical records to time-constrain geological and hazardous events: an example from the eastern Tyrrhenian Sea in the last 120 ka. Glob. Planet. Change, 113, 91-109.

Iorio M., Capretto G., Petruccione E., Marsella E., Aiello G., Senatore M.R. (2014b) Multi-proxy analysis in defining sedimentary processes in very recent prodelta deposits: the northern Phlegrean offshore example (Eastern Tyrrhenian margin). Rend. Lincei, 25 (2), 237-254.

Lane C.S., Brauer A., Marta An-Puertas C., Blockley S.P.E, Smith V.C., Tomlinson E.L., (2015) The Late Quaternary tephrostratigraphy of annually laminated sediments from Lake Meerfelder Maar, Germany. Quat. Sci. Rev., 122, 192-206.

Lambeck, K., Chappell, J., (2001) Sea-level change through the last glacial cycle. Science, 292, 679-686.

Lambeck, K., Rouby, H., Purcell, A., Sun, Y., \& Sambridge, M. (2014). Sea level and global ice volumes from the Last Glacial Maximum to the Holocene. Proceedings of the National Academy of Sciences, 111(43), 15296-15303.

Le Maitre R.W. 2005. Igneous Rocks. A Classification and Glossary of Terms. Recommendations of the International Union of Geological Sciences Subcommission on the Systematics of Igneous Rocks. Cambridge University Press, Cambridge.

Lykousis V., Sakellariou D., Roussakis G. (2003) Prodelta slope stability and associated coastal hazards in tectonically active margins: Gulf of Corinth (NE Mediterranean). In: Locat J, Mienert J (eds) Submarine mass movements and their consequences. Kluwer Academic Publishers, pp 433-440

Lirer F., Sprovieri M., Ferraro L., Vallefuoco M., Capotondi L., Cascella A., Petrosino P., Insinga D.D., Pelosi N., TAMBurRino S., LubritTo C. (2013) Integrated stratigraphy in the eastern Tyrrhenian sea. Quat. Int., 292, 71-85.

LISIECKI L.E., RAYMO M.E. (2005) A Pliocene-Pleistocene stack of 57 globally distributed benthic D18O records. Paleoceanography, VOL. 20, PA1003, doi:10.1029/2004PA001071, 2005.

lofi J., Rabineauc M., Gorinid C., Berne S., Clauzon G., De Clarens P., Dos Reise A.T., Mountain G.S., Ryan W.B.F., STECKLER M.S., Foucheta C. (2003) Plio-Quaternary prograding clinoform wedges of the western Gulf of Lion continental margin (NW Mediterranean) after the Messinian Salinity Crisis. Mar. Geol., 198(3-4), 289-317.

Lowe D.J. (2011) Tephrochronology and its application: a review. Quat. Geochronol., 6, 107-153. 18 
MALINVERNO A. \& RYAN W.B.F. (1986) Extension in the Tyrrhenian Sea and shortening in the Apennines as result of arc migration driven by sinking of the lithosphere. Tectonics, 5 (2), 227-245.

Marani M., TAViani M., Trincardi F., Argnani A. (1986) Pleistocene progradation and postglacial events of the NE Tyrrhenian continental shelf between the Tiber river delta and Capo Circeo. Mem. Soc. Geol. It., 36, 67-89.

Margaritelli G., Vallefuoco M., Di Rita F., Capotondi L., Bellucci L.G., Insinga D.D., Petrosino P., Bonomo S., Cacho I., Cascella A., Ferraro L., Florindo F., Lubritto C., Lurcock P.C., Magri D., Pelosi N., RetTori R., LiRer F. (2016) Marine response to climate changes during the last five millennia in the central Mediterranean Sea. Glob. Planet. Change, 142, 53-72.

MARIANI M. \& PRAto R. (1988) I bacini neogenici costieri del margine tirrenico. Approccio sismico-stratigrafico. Mem. Soc. Geol. It., 41, 519-531.

MARTORELLI E., CHIOCCI F.L., ORLANDO L. (2010) Imaging continental shelf shallow stratigraphy by using different high resolution seismic sources: an example from the Calabro-Tyrrhenian margin (Mediterranean sea). Braz. J. Oceanogr., 58(1), http://dx.doi.org/10.1590/S167987592010000500006.

MAselli V. \& TRInCARDi F. (2013) Man made deltas. Scientific Reports, 3, 1926 doi:10.1038/srep01926.

Milia A., (1998a) Le unità piroclastiche tardo-quaternarie del Golfo di Napoli, Geogr. Fis. Dinam. Quat., 21, 147-153.

Milia A. (1998b) Stratigrafia, strutture deformative e considerazioni sull'origine delle unità deposizionali oloceniche del Golfo di Pozzuoli (Napoli). Boll. Soc. Geol. It., 117, 777-787.

Maselli, V., Trincardi, F., Asioli, A., Ceregato, A., Rizzetto, F., Taviani, M. (2014) Delta growth and river valleys: The influence of climate and sea level changes on the South Adriatic shelf (Mediterranean Sea). Quat. Sci. Rev., 99, 146-163.

Milia A. \&TORRENTE M.M. (2015) Tectono-stratigraphic signature of a rapid multistage subsiding rift basin in the Tyrrhenian-Apennine hinge zone (Italy): A possible interaction of upper plate with subducting slab. J. Geodyn., 86, 42-60.

Milia A., Raspini A., Torrente M.M. (2007) The dark nature of Somma-Vesuvius volcano: evidence from the $3.5 \mathrm{ka}$ B.P. Avellino eruption. Quat. Int., 173/174, 57-66.

Milia A., Molisso F., Raspini A., SaCchi M., Torrente M.M. (2008) Syneruptive features and sedimentary processes associated with pyroclastic currents entering the sea: the AD79 eruption of Vesuvius, Bay of Naples, Italy. J. Geol. Soc. London, 165, 839-848.

Milia A., Torrente M.M., Massa B., IAnnace P. (2013) Possible changes in rifting directions in the Campania margin (Italy): New constrains for the Tyrrhenian sea opening. Glob. Planet. Change, 109, 3-17.

Mitchum R.M. \& VAIL P.R. (1977) Seismic stratigraphy and global changes of sea level, part 7: stratigraphic interpretation of seismic reflection patterns in depositional sequences. In: PAYTON C.E. (Ed.) Seismic Stratigraphy - Applications to Hydrocarbon Exploration. Memoir 26, American Association of Petroleum Geologists, pp. 135-144. 
Morabito, S., Petrosino, P., Milia, A., Sprovieri, M., Tamburrino, S. (2014) $A$ multidisciplinary approach for reconstructing the stratigraphic framework of the last $40 \mathrm{ka}$ in a bathial area of the eastern Tyrrhenian Sea. Glob. Planet. Change 123, 121-138.

Orsi G., D’Antonio M., DE Vita S \& Gallo G. (1992) The Neapolitan Yellow Tuff, a largemagnitude trachytic phreato-plinian eruption; eruptive dynamics, magma withdrawal and caldera collapse, J. Volcanol. Geotherm. Res, 53, 275-287.

Orsi G, Civetta L, D’Antonio M, Di Girolamo P, Piochi M (1995) Step-filling and development of a three-layers magma chamber: the Neapolitan Yellow Tuff case history. J. Volcanol. Geotherm. Res. 67, 291-312.

Paterne, M., Guichard, F., Labeyrie, J., Gillot, P.Y., Duplessy, J.C. (1986) Tyrrhenian Sea tephrochronology of the oxygen isotope record for the past 60.000 years. Mar. Geol. 72, 259-285.

Pellegrini C., Maselli V., Cattaneo A., Piva A., Ceregato A., Trincardi F. (2010) Anatomy of a compound delta from the post-glacial transgressive record in the Adriatic Sea. Mar. Geol., 362, 43-59.

Petruccione E., Aiello G., Capretto G., Senatore M.R., Marsella E., Iorio M. (2011) Holocene sedimentary and gravitative processes in highstand prodelta deposits on the Cuma outer shelf (Eastern Tyrrhenian sea): an integrated approach. DTA6/2011, CNR, Dipartimento Terra e Ambiente, 771-784.

Rolandi G., Bellucci F., Heizler M.T., Belkin H.E., De Vivo B. (2003) Tectonic controls on the genesis of ignimbrites from the Campanian Volcanic Zone, southern Italy. Mineral. Petrol., 79, 331.

Romano P., Santo A., Voltaggio M. (1994) L'evoluzione geomorfologica della pianura del fiume Volturno (Campania) durante il tardo Quaternario (Pleistocene medio-superiore-Olocene). Il Quaternario, 7 (1), 41-56.

Rosi M. \& Sbrana A. (1987) Phlegrean Fields, C.N.R., Quaderni de "La ricerca scientifica”, 1149, pp176.

Sacchi M., Insinga D., Milia A., Molisso F., Raspini A., Torrente M.M., Conforti A. (2005) Stratigraphic signature of the Vesuvius 79 AD event off the Sarno prodelta system, Naples Bay. Mar. Geol., 222-223, 443-469.

Sacchi M., Molisso F., Violante C., Esposito E., Insinga D.D., Lubritto C., Porfido S., Toth T. (2009) Insights into flood-dominated fan-deltas: very high resolution seismic examples off the Amalfi cliffed coasts, eastern Tyrrhenian sea. Geol. Soc. London, Spec. Publ., 322, 33-71.

Sacchi M., Pepe F., Corradino M., Insinga D.D., Molisso F., Lubritto C. (2014a) The Neapolitan Yellow Tuff caldera offshore the Campi Flegrei: Stratal architecture and kinematic reconstruction during the last $15 \mathrm{ky}$. Mar. Geol., 354, 15-33.

Sacchi M., Molisso F., Pacifico A., Vigliotti M., Sabbarese C., Ruberti D. (2014b) LateHolocene to recent evolution of Lake Patria, South Italy: An example of a coastal lagoon within a Mediterranean delta system. Glob. Planet. Change, 117, 9-27.

Scarpati C., Cole P., Perrotta A. (1993) The Neapolitan Yellow Tuff - a large volume multiphase eruption from Campi Flegrei, Southern Italy. Bull. Volcanol., 55, 343-356. 
Siani, G., Sulpizio, R., Paterne, M., Sbrana, A. (2004) Tephrostratigraphy study for the last $18.000{ }^{14} \mathrm{C}$ years in a deep-sea sediment sequence of the South Adriatic. Quat. Sci. Rev. 23, 24852500 .

Smith V.C., IsAia R., PeARCE N.J.G. (2011) Tephrostratigraphy and glass compositions of post 15kyr Campi Flegrei eruptions: implications for eruption history and chronostratigraphic markers. Quat. Sci. Rev., 30, 3638-3660.

Tomlinson E.L., Arienzo I., Wulf S., Smith V.C., Carandente A., Civetta L., Hardiman M., Lane C.S., Orsi G., Rosi M., Thirlwall M.T., Muller W., Menzies M.A. (2012) Geochemistry of the Phlegraean Fields (Italy) proximal sources for major Mediterranean tephras: implications for the dispersal of Plinian and co-ignimbritic components of explosive eruptions. Geochim. Cosmochim. Acta 93, 102-128. doi:10.1016/j.gca.2012.05.043

TORRENTE M.M. \& Milia A. (2013) Volcanism and faulting of the Campania margin (Eastern Tyrrhenian sea, Italy): a three-dimensional visualization of a new volcanic field off Campi Flegrei. Bull. Volcanol., 75-719, doi 10.1007/s00445-013-0719-0.

TrincARdi F., CORREgGIARI A., Roveri M. (1994) Late Quaternary trasgressive erosion and deposition in a modern epicontinental shelf: the Adriatic semi-enclosed basin. Geo-Mar Lett., 14, 41-51.

TRINCARDI F., NORMARK W. (1988) Sediment waves on the Tiber prodelta slope: interaction of deltaic sedimentation and currents along the shelf. Geo-Mar Lett. 8(3):149-157. doi:10.1007/bf02326091

VAIL P.R., Mitchum R.M., ThOMPSOn S. (1977) Seismic stratigraphy and global changes of sea level, part 3: relative changes of sea level from coastal onlap. In: PAYTON C.E. (Ed.) Seismic Stratigraphy - Applications to Hydrocarbon Exploration. Memoir vol. 26, American Association of Petroleum Geologists, pp. 63-81.

Van Wagoner J.C., Posamentier H.W., Mitchum R.M., Vail P.R., Sarg J.F., Loutit T.S., HARDENBOL J. (1988) An overview of sequence stratigraphy and key definitions. In: Wilgus C.K., Hastings B.S., Kendall C.G. St. C., Posamentier H.W., Ross C.A., Van Wagoner J.C. (Eds.) Sea level. Changes- an integrated approach. SEPM Special Publication, 42, 39-45.

Zanchetta, G., Sulpizio, R., Roberts, N., Cioni, R., Eastwood, W.J., Siani, G., Caron, B., PATERne, M., SANTACROCE, R., 2011. Tephrostratigraphy, chronology and climatic events of the Mediterranean basin during the Holocene: An overview. The Holocene 21(1), 33 -52.

ZECCHIN M. \& CATUNEANU O. (2013) High-resolution sequence stratigraphy of clastic shelves I: Units and bounding surfaces. Mar. Petrol. Geol., 39, 1-25. 


\section{FIGURE CAPTIONS}

Figure 1: Location of the study area in the northern Phlegraean Fields offshore, along the eastern Tyrrhenian margin. The seismic lines and the C1161 core used in this study are reported.

Figure 2. (I) Grain size, (II) Lithology and (III) Raw Volume Magnetic susceptibility logs of core C1161. Black star and label $V$ indicate the stratigraphic height of tephra sample and the top of the volcanic marker, respectively (modified from Iorio et alii, 2014b).

Figure 3: a) TAS (Total Alkali/Silica) classification diagram (Le Maitre, 2005) of C1161/1 tephra. b) $\mathrm{FeO}$ vs $\mathrm{SiO}_{2}$ and c) $\mathrm{CaO}$ vs $\mathrm{SiO}_{2}$ variation diagrams with composition of the analysed tephra. Single glass data (WDS) of the NYT proximal deposits (Upper Member and Lower Member) are reported for comparison (from Tomlinson et alii, 2012).

Figure 4: ChirpProfile (trasf_0; modified from Iorio et alii, 2014b) showing the seismostratigraphic architecture of the area (see location in Fig. 1). Notice the volcanic marker (V) marked in red. See text for explanation.

Figure 5: Chirp Profiles M196, M197 and M198 (see location in Fig. 1). Notice the volcanic marker (V) marked in red. See text for the explanation.

Figure 6: Chirp Profiles M198A (modified from Iorio et alii, 2014b), M199 and M200 (see location in Fig. 1). Notice the volcanic marker (V) marked in red. See text for the explanation.

Figure 7: Map of the depth trend of the $V$ reflector (NYT) from the sealevel. The colorimetric scale represents the variation of the depth in milliseconds with the corresponding values in meters. The inset on the top right shows a 3D model of the NYT trend.

Figure 8: Map of the depth trend of the $V$ reflector (NYT) from the seafloor. The colorimetric scale represents the variation of the depth in milliseconds with the corresponding values in meters. The inset on the top right shows a 3D model of the NYT trend.

22

https://mc.manuscriptcentral.com/ijg 


\section{TABLE CAPTIONS}

Table 1: Location, orientation, and average water-depths details of the analyzed Subbottom Chirp lines.

Table 2: Major element content of single glass (wt. \%) in sample C1161/1. All analyses are recalculated water-free to 100 . 
On the occurrence of the Neapolitan Yellow Tuff tephra in the Northern Phlegraean

Fields offshore (Eastern Tyrrhenian margin; Italy)

Sulla presenza del tefra del Tufo Giallo Napoletano nell'offshore settentrionale dei Campi Flegrei (margine tirrenico orientale, Italia).

Gemma Aiello (1*), Donatella Domenica Insinga (1), Marina Iorio (1) Agostino Meo (2) Maria Rosaria Senatore (2)

(1) Istituto per l'Ambiente Marino Costiero, Consiglio Nazionale delle Ricerche (CNR), Calata Porta di Massa, Porto di Napoli, 80133, Napoli, Italy

(2) Dipartimento di Scienze e Tecnologie, Università degli Studi del Sannio, CoNISMA, Benevento, Italy

(*) Corresponding Author

Gemma Aiello

Istituto per l'Ambiente Marino Costiero

Consiglio Nazionale delle Ricerche (CNR)

Calata Porta di Massa - Porto di Napoli

80133 - Napoli -Italy

Tel. 39-81-5423820 Fax: 39-81-5423888

Email: gemma.aiello@iamc.cnr.it 


\section{ABSTRACT}

A main volcanic marker has been identified for the first time on the continental shelf of the northern Phlegraean Fields in the Gaeta Gulf (Campania region, eastern Tyrrhenian margin, Italy) by means of Subbottom Chirp profile grid and stratigraphic analysis of a core collected on the slope. In the seismic sections, the core bottom corresponds to the top of a continuous and parallel reflector $(V)$ interbedded within the transgressive deposits of the Late Quaternary-Holocene depositional sequence. The Transgressive System Tract deposits are particularly thick compared to the majority of the transgressive deposits of other shelf settings. This might be due to the input of pyroclastic and volcanoclastic deposits related to the intense eruptive activity of the Campania Plain during the Late Pleistocene-Holocene time span. Undulations and pockmarks are the main morphological features of the sea floor and they might be linked to gas uprising, widely detected in the study area. The $V$ reflector is located on the shelf from northeast to southwest at different depths, ranging from $10 \mathrm{~ms}$ (about $8 \mathrm{~m}$ ) to $30 \mathrm{~ms}$ (about $25 \mathrm{~m}$ ) below sea floor and it can be mapped down to the continental slope. The geological calibration of this continuous reflector coupled with tephrostratigraphic analysis, allowed to correlate it with the Neapolitan Yellow Tuff deposits emplaced at Phlegraean Fields at ca. 15 ka.

Key words: Neapolitan Yellow Tuff, Gaeta Gulf, Phlegraean Fields, coastal volcanism, seismic stratigraphy. 


\section{INTRODUCTION}

Coastal volcanism along the Campania margin plays a key role in the stratigraphic architecture of adjacent marine settings since it leads to several types of processes that supply large volumes of pyroclastic and volcanoclastic deposits over wide sectors of the continental shelf-slope-basin system during short time spans (INSINGA et alii, 2006; Milia et alii, 2007; DE AlteriIs et alii, 2010, Budillon et alii, 2012). Pyroclastic deposits, in particular, are delivered to the sedimentary environment following a variety of transport processes such as fallout, flows and surges which can evolve across the continental shelf and slope in sediment failure or hyperpicnal flows (SACCHI et alii, 2005, 2009; MiLIA et alii, 2008). As a result of their synchronous deposition over large areas, pyroclastics (tephra) form important stratigraphic markers and event signals in the marine record (e.g. LOWE, 2011; ZANCHETTA et alii, 2011; INSINGA et alii, 2014 and references therein) and such findings are particularly frequent along the Campania margin in the Naples and Salerno gulfs and offshore Cilento (e.g.; BUCCHERI et alii, 2002; IORIO et alii, 2004; SACCHI et alii, 2005; INSINGA et alii, 2008; LIRER et alii, 2013; IORIO et alii, 2014a). A detailed geological literature exists on the structural and stratigraphic relationships between marine and volcanic units in the Gaeta Gulf since the Quaternary, however it is mainly based on seismic interpretations and onshore borehole data (Aiello et alii, 2000; Milia et alii, 2013; Torrente \& Milia, 2013; Milia \& Torrente, 2015). Core data regarding the marine stratigraphic record and the tephra deposits interbedded within are still very few and mainly related to the Holocene deposits (IORIO et alii, 2014b; MARGARITELLI et alii, 2016).

In this paper we report, for the first time, on the occurrence of the Neapolitan Yellow Tuff deposit in the southern sector of the Gaeta Gulf, between the Volturno mouth and the Cuma town, offshore the Northern Phlegraean Fields (Fig. 1). Based on gravity core data and high-resolution seismic profiles, the Neapolitan Yellow Tuff deposit was characterized both in terms of lithology and 
chemistry and its seismic signature was described and mapped. The obtained results aim to provide a contribution to the tephrostratigraphic framework of the southern Gaeta Gulf and highlight the significant role of this tephra in regards to the stratigraphic architecture of Northern Phlegraean offshore.

\section{GEOLOGIC SETTING}

The study area represents the seaward extension of the northern sector of the Campania Plain (Fig. 1), a coastal plain of southern Italy located along the Latium-Campania margin. This latter is characterized by Plio-Pleistocene tectonically-downthrown areas genetically related to normal and strike-slip faults linked to the geological evolution of the Eastern Tyrrhenian margin (“peri-tyrrhenian basins”; FABBRI et alii, 1981 BARTOLE et alii, 1984; MALINVERNO \& RYAN, 1986; MARIANi \& Prato, 1988; Florio et alii, 1999; BRUNo et alii, 2000; Aiello et alii, 2000, 2011a; 2011b; CASCIELLO et alii, 2006) and filled by coastal and marine deposits reaching thicknesses of several thousand of meters. In particular, in the Gaeta basin, extensional tectonics has been active along systems of ESE-WNW, E-W and NE-SW trending normal faults, related to strike-slip tectonic movements that took place mainly during the Late Pliocene-Early Pleistocene time interval (BARTOle et alii, 1984, Aiello et alii, 2000, BRUNO et alii, 2000).

The depositional geometries of strata pertaining to the Plio-Quaternary basin fill are similar to those recognized in the adjacent Terracina basin (AIELLO et alii, 2000). The lower seismic sequences are characterized by parallel horizons and are strongly affected by wedging and growth as a consequence of synsedimentary tectonics. The upper seismic sequences show progradational geometries led by sedimentary feeding from the Garigliano and Volturno rivers and controlled by eustatic sea-level fluctuations during Quaternary times (AIELLO et alii, 2000).

Regional geological evidence, coupled with seismo-stratigraphic interpretations, has suggested that the Volturno basin represents a half-graben structure, characterized by blocks downthrown along 
normal faults and filled by four main seismic units (identified as D1-D4; AIELLO et alii, 2011a; 2011b). Rapid flooding of coastal Volturno Plain culminated at 6.5 cal. ka B.P. (AMORosi et alii, 2012 and references therein), leading to a narrowing of the shelf to a maximum width of $16 \mathrm{~km}$ in correspondence to Volturno river mouth and a minimum width in the Cuma offshore (about $10 \mathrm{~km}$ ). The shelf break occurs at water depths ranging between 120-125 m.

The stratigraphic architecture of the continental shelf during the Late Pleistocene - Holocene time interval is an incomplete $4^{\text {th }}$ order depositional sequence, that shows an inner strata organization with minor downlap surfaces and erosional truncations separating different phases of progradation (MARANi et alii, 1986; Aiello et alii, 2000, 2011a; 2011b; IORIO et alii, 2014b). The last progradation started at about $130 \mathrm{ka}$ and ended at about $18 \mathrm{ka}$ (CATTANEO et alii, 2002; LOFI et alii, 2003; Duvail et alii, 2005; LisieCKI \& RAYMo, 2005; PELlEgrini et alii, 2010; CAPRARO et alii, 2011; MASELLI \& TRINCARDI, 2013; MASELLI et alii, 2014). An abrupt erosional surface separates the forced regression and lowstand deposits from the overlying sediments, that were formed between $18 \mathrm{ka}$ and $5 \mathrm{ka}$ during the last sea level rise (transgressive deposits; FABBRI et alii, 2002; Cattaneo \& Steel, 2003; Trincardi et alii, 1994) and from about 5 ka to present times during the recent sea level highstand (highstand deposits; HUNT \& TUCKER, 1992; COPPA et alii, 1996; BUCCHERI et alii, 2002). Since ca. 6.5 cal. ka, the highstand phase has marked the onset of the present-day Volturno delta and the progradation of the adjacent coastal plain, ranging between 3 and 6 km (BARra et alii, 1996; Bellotti, 2000; RomANo et alii, 2004; AmOrosi et alii, 2012; SACCHI et alii, 2014b). Holocene wedge decreases in thickness towards the shelf edge. The continental slope is characterized by a uniform profile and is incised by several submarine gullies (Chiocci \& CASAlbore, 2011; Petruccione et alii, 2011). 


\subsection{The NeAPolitan Yellow TufF}

Intense volcanism took place at several centers of the Campania Plain since at least the middle Pleistocene (DE VIVo et alii, 2001; ROLANDI et alii, 2003; Di VITO et alii, 2008; INSINGA et alii, 2014) as a consequence of the extensional tectonics that affected the eastern Tyrrhenian margin. During the Late Pleistocene, caldera-forming eruptions occurred inside the Campania Plain at Phlegraean Fields district with the most recent event of the Neapolitan Yellow Tuff (NYT) at 14.9 $\pm 0.4 \mathrm{ka}$ (DEINO et alii, 2004). It erupted an estimated volume of about $45 \mathrm{~km}^{3}$ DRE (Dense Rock Equivalent) covering an area of more than $1000 \mathrm{~km}^{2}$ and producing a caldera collapse of about $10 \mathrm{~km}$ in diameter (SCARPATI et alii, 1993; ORSI et alii, 1995). On the periphery of Phlegraean Fields and in the Campania Plain, the NYT exhibits high thickness and is characterized by a succession of pyroclastic fall and flow deposits (Lower and Upper Member, respectively; ORSI et alii, 1992, 1995). The Lower Member is compositionally bimodal (trachytic and trachyphonolitic) whereas the Upper Member spans the full compositional range between the two Lower Member populations (TOMLINSON et alii, 2012). Distal ash-fall deposits spread over wide areas up to northern Europe in marine and continental archives (e.g. PATERNE et alii, 1986; CALANCHI et alii, 1998; SIANI et alii, 2004; BOURnE et alii, 2010; LANE et alii, 2015 and references therein). By contrast, far from the vent on land, such as in the Volturno coastal plain, the NYT is absent due to the removal-burial by fluvial processes (AMOROSI et alii, 2012). The NYT products had a strong impact on the sedimentary processes and, ultimately, on the stratigraphic record of adjacent marine settings, as documented in the Pozzuoli Bay (AIELLO et alii; 2012; SACCHI et alii, 2014a; AiELlo et alii, in press.)

\section{DATASET AND METHODS}




\subsection{GRAVITY CORE C1161}

The core C1161 was recovered at $144 \mathrm{~m}$ below the sea level on the right side of an upper slope gully in the northern sector of Phlegraean Fields offshore (Fig. 1) using a $6 \mathrm{~m}$ long gravity corer with liners of $9 \mathrm{~cm}$ in diameter. Core recovery was about $50 \%$ with an estimated compaction of about $15 \%$. The stratigraphic record consists of ca. 2.62 m-thick Holocene deposits which have been studied in detail with respect to their lithological, sedimentological, petrophysical and seismic aspects (IORIO et alii, 2014b). The sediments are mainly represented by silty and clayey deposits. A grain-size variation occurs at about $1.60 \mathrm{~m}$ below sea floor down to the core bottom, where sandy and gravelly fractions, mainly made up of bioclastic and pumiceous clasts, occur. Sedimentological analysis suggested a high energy depositional environment (IORIO et alii, 2014b), in agreement with the location of the core on a submarine channel levee. The integrated petrophysical (high magnetic susceptibility values) and seismic analysis correlated the bottom of the core to the top of a seismic reflector interpreted as being of volcanic origin ( $V$ in IORIO et alii, 2014b). The sediment was sampled and chemically analysed for the purposes of this work.

\subsubsection{TEPHRA ANALYSIS}

The non visible-tephra (cryptotephra) found at the core bottom and corresponding to the top of the reflector $V$ in IORIO et alii (2014b), was sampled, disaggregated in distilled water and wet sieved at $63,90,125$ and $250 \mu \mathrm{m}$ in order to remove the fine-grained sediment. The sieved material was cleaned with an ultrasonic probe, dried at $60^{\circ} \mathrm{C}$ and then it was observed at the optical microscope in order to describe the lithology and to pick up fresh glasses for the chemical characterization. At least 25 juvenile fragments (pumiceous and glass shards) were mounted on epoxy resin and suitably polished for microprobe analysis.

Energy Dispersive Spectrometric (EDS) analyses were performed using JEOL JSM-5310 SEM at CISAG (Centro Interdipartimentale di Servizio per Analisi Geomineralogiche) of the University of 7 
Napoli "Federico II" through Oxford Instruments Microanalysis Unit, equipped with an INCA Xact detector. The operating conditions were $15 \mathrm{kV}$ primary beam voltage, $50-100 \mathrm{~m}$. A filament current, $50 \mathrm{sec}$ acquisition time with variable spot size was adopted during the data elaboration. A correction for matrix effect was performed using INCA version 4.08 software that used the XPP correction routine, based on a Phi-Ro-Zeta approach. Moreover, a primary calibration was performed using international mineral and glass standards USMN reference samples according to the following scheme: Anorthoclase 133868 for $\mathrm{Si}$ and $\mathrm{Na}$, Microcline 143966 for $\mathrm{Al}$ and K, Fayalite 85276 for Mn, Anorthite 137041 for Ca, Hornblende 143965 for Fe, Mg and Ti, Scapolite 6600-1 for $\mathrm{Cl}$, and Apatite 104021 for $\mathrm{P}$.

Precision and accuracy were assessed using the rhyolitic glass USMN 75854 as secondary standard. Mean precision was $<5 \%$ for $\mathrm{SiO}_{2}, \mathrm{Al}_{2} \mathrm{O}_{3}, \mathrm{~K}_{2} \mathrm{O}, \mathrm{CaO}$ and $\mathrm{FeO}$, and around $10 \%$ for the other elements.

\subsection{SEISMIC DATA ACQUISITION}

Six Chirp profiles, collected in the frame of research projects on marine geological mapping on the continental shelf off the Campania region (penetration between 25 and $50 \mathrm{~m}$ below the sea bottom using an average velocity of $1.550 \mathrm{~m} / \mathrm{sec}$ for time-to-depth conversion), provided the stratigraphic framework to recognize the volcanic marker (Table 1). High resolution seismic stratigraphy has been described in detail as a valuable technique of analysis of seismic profiles (Mitchum et alii, 1977; VAIL et alii, 1977; VAN WAGONER et alii, 1988; CATUNEANU et alii, 2009; ZECCHIN \& CATUNEANU, 2013) and has been herein applied in the geological interpretation of seismic profiles. Positioning was established through the Starfix differential GPS. The software IHS Kingdom ${ }^{\circledR}$ was used for the processing, management and interpretation of the seismic lines. The seismostratigraphic results were integrated with stratigraphic results previously obtained on the same dataset (PETRUCCIONE et alii, 2011; IORIO et alii, 2014b) and with new data from core samples 
(tephrostratigraphy)

\section{RESULTS}

\subsection{TEPHROSTRATIGRAPHY}

The analyzed cryptotephra, here labelled as C1161/1, is represented by medium- to fine-grained ash made up of light grey elongated pumices, light-grey glass shards with fibrous and bubble wall junction morphologies and brown blocky glass shards. Loose crystals of feldspar, biotite and clinopyroxene occur in the deposit along with rare lithics and bioclasts. According to the TAS (Total Alkali/Silica; LE MAITRE, 2005) classification diagram, glasses from C1161/1 straddle the trachyte/phonolite (hence being trachyphonolites) and the tephriphonolite/latite boundary forming a continuum of compositions (Fig. 3a). A few points fall within the trachyte and phonolite fields. The silica values range from 54.90 wt. $\%$ to 62.90 wt. $\%, \mathrm{CaO}$ and $\mathrm{FeO}_{\text {tot }}$ from 1.70 wt.\% to 5.55 wt.\% and from 2.50 wt. $\%$ to 6.66 wt. $\%$ respectively, $\mathrm{MgO}$ from $0.27 \mathrm{wt} \%$ to $2.36 \mathrm{wt} \%$ whereas $\mathrm{Al}_{2} \mathrm{O}_{3}$ is approximately constant. The alkali content ranges from $10.78 \mathrm{wt} . \%$ to $14.20 \mathrm{wt} . \%$ (Tab. 2).

\subsection{HIGH RESOLUTION SEISMIC STRATIGRAPHY}

The seismo-stratigraphic interpretation of six Chirp seismic profiles, significant for the stratigraphic architecture of the northern Phlegraean offshore (Tab.1), has been carried out in order to map the trend of the seismic horizon $V$.

The oldest seismic unit is represented by the Falling Stage System Tract (FSST; Figs. 4, 5 and 6). It is characterized by seismic reflectors in offlap, grading seawards into a wedge-shaped seismic unit, interpreted as the Shelf Margin System Tract (SMST). Due to the limited penetration of the seismic sections, the FSST and the SMST are not well detectable. In the M198 seismic profile (Fig. 5), the SMST has not been recognized, because the present-day shelf break is shallower than the one 
corresponding to the last phase of sea level lowstand (120 m bsl; CHAPPELL AND SHACKLETON, 1986; LAMBeCK AND CHAPPELl, 2001; LAMBECK et alii, 2014). In the M196 seismic profile, the FSST and the SMST are bounded upwards by the transgressive surface (T), marking the first major flooding of the continental shelf following the lowstand phase (Fig. 5). In this case the transgressive surface coincides with the 4 th order sequence boundary. The transgressive paralic deposits have been observed mainly on NW-SE trending seismic profiles and they are characterised by variable thickness (Fig. 4). They rest in downlap on the $\mathrm{T}$ surface and are separated from the overlying marine deposits by the ravinement surface (RS). Both the transgressive surface (T) and the ravinement surface (RS) appear as marked irregular erosional surfaces, gently deepening seawards (Figs. 4, 5 and 6). The FSST has been interpreted as Upper Pleistocene prograding deposits and it is overlaid by a very thick Transgressive System Tract (TST). The TST marine deposits onlap onto the RS (Figs. 4 and 5). They are characterized by parallel and continuous seismic reflectors with moderate to low amplitude. The TST upper boundary is the maximum flooding surface (MFS), which is often interrupted by shallow gas pockets (Figs. 4, 5 and 6). Above the MFS surface, the Highstand System Tract (HST) is represented by a wedge-shaped seismic unit thickening landwards. It is distinguished by discontinuous seismic reflectors with a moderate high amplitude.

The $V$ reflector is parallel and displays a high amplitude. It has been continuously detected from the shelf to the slope within the transgressive marine deposits (Figs. 4, 5 and 6). On the inner shelf its continuity is interrupted by shallow gas pockets. The $V$ depths ranges from $2 \mathrm{~ms}$ bsf on the slope to $28 \mathrm{~ms}$ bsf on south-eastern sector of the continental shelf. The overlying TST and HST deposits are affected by undulations, often downthrown by small-scale normal faults having a limited offset (IORIO et alii, 2014b). Undulations mainly occur in the outer shelf controlling the thickening of sediments. 


\section{DISCUSSION}

\subsection{TEPHRA CORRELATION}

The major element features of cryptotephra C1161/1 are typical of mildly silica undersaturated to saturated potassic products of Phlegraean activity occurred during the Late Pleistocene-Holocene time interval (SMITH et alii, 2011; TOMLINSON et alii, 2012). The wide chemical composition ranging from trachyphonolites to less evolved portions and the finding of the tephra within the transgressive marine deposits, indicate the correlation of C1161/1 to the NYT products dated via the ${ }^{40} \mathrm{Ar} /{ }^{39} \mathrm{Ar}$ method at $14.09 \pm 0.4 \mathrm{ka}$ (DEINO et alii, 2004) and later refined to $14.11 \pm 0.21$ cal. ka B.P. (BLOCKLEY et alii., 2008). In detail, chemistry of our tephra is well within the NYT-Upper Member population but a contribution of the Lower Member cannot be discarded (Fig. 3a-b-c). The NYT has been correlated to marine tephra C-2 up to $250 \mathrm{~km}$ from the Phlegraean Fields in the Tyrrhenian and Adriatic seas and it likely records both the Lower and Upper Member composition (e.g. PATERnE et alii., 1986; CALANCHI et alii., 1998; SiAnI et alii, 2004, BouRne et alii, 2010; MoRABITO et alii, 2014). At very distal sites in northern Europe, the NYT tephra records only the bi-modal Lower Member (LANE et alii, 2015 and references therein). However, in the Tyrrhenian and Adriatic seas the correlation is not straightforward since a number of tephras with strong chemical similarity to the NYT immediately underlies tephra C-2 (SIANI et alii, 2004; BouRnE et alii, 2010; MORABITO et alii, 2014). This tephra framework may be the result of a complex stratigraphy on land that led some authors to propose different hypotheses about the origin of the NYT deposits: 1) they were emitted at different times from different eruptive centers (e.g. Rosi \& SBRANA, 1987); 2) they were the result of a single event on land perhaps from multiple vents (e.g. ORSI et alii, 1992, 1995, SCARPATI et alii, 1993). According to data from the southern Adriatic, SIANI et alii (2004) suggested that the NYT could represent the last event of a series of eruptions closely spaced in time (ca. 600 years), thus aiming to solve the volcanological issue. This might be in agreement with our finding of the NYT tephra at the top of the $V$ main volcanic reflector. It is 
possible, in fact, that the $V$ marker correlates with other pyroclastic and volcanoclastic deposits from eruptions closely spaced in time to the NYT and immediately underlying it. However, the need to improve the stratigraphic analysis of the whole $V$ reflector at other sites of the Gulf is required to confirm or deny the above hypothesis.

\subsection{Stratigraphy and $V /$ NYT marker}

The seismostratigraphic data obtained from the measurements of depths allowed to construct sketch diagrams which show the pattern of the NYT tephra in relation with the depth calculated from both the sea level and the sea floor (Figs. 7 and 8, respectively). Three-dimensional views of the NYT/seismic reflector are also reported (insets in Figs. 7 and 8).

The depth pattern of the NYT seismic reflector measured from the sea level depicts a surface regularly dipping towards south-west, proceeding from the shelf to the basin (Fig. 7). The thickness of sediments overlying the NYT deposits is very high on the shelf (Fig 8) and, in detail, ranges from $10 \mathrm{~ms}$ (about $8 \mathrm{~m}$ ) to $30 \mathrm{~ms}$ (about $25 \mathrm{~m}$ ) (Fig. 8). Greater depths, between $26 \mathrm{~ms}$ and $30 \mathrm{~ms}$ are reached along a NE-SW trending area located in the central part of the shelf where sediment undulations, gas charged sediments, and pockmarks, identified in Iorio et alii ( 2014 b), have been mapped (Fig. 8). These features are typical of other examples where undulated reflectors characterize thick prodelta wedges on the Mediterranean shelves (e.g., TRINCARDI \& NORMARK 1988; CORREGGIARI et alii, 2001; LyKOUSIS et alii, 2003). The origin of undulations in the study area has been largely debated in Iorio et alii (2014b). The authors related them mainly to sheardominated failure with limited downslope displacement rather than erosional/depositional processes. The displacement was likely favored by high sediment supply, high-water content, fluid escapes and shelf gradient deepening. 
In this study case, the seismic facies related to undulations are discontinuous, probably due to frequent occurrence of gas within the sediments (ERCILLA et alii, 1994, 1995; CORREGGIARI et alii, 2001). In fact, in correspondence of each undulation we can observe, on the seismic profiles, the typical transparent seismic facies correlated to the presence of gas (Figs. 4, 5 and 6).

The NYT is interlayered in the TST marine deposits (Figs. 4, 5 and 6) which are particularly developed in this area compared to the majority of TST deposits on the continental shelves of other settings (Trincardi et alii, 1994; Cattaneo \& Steel, 2003; Martorelli et alii, 2010; Pellegrini et alii, 2010; ZeCChin \& CAtuneanu, 2013), such as in the Salerno Gulf where the TST is characterized by a thin succession of sediments in spite of active fluvial supply during that time span (BUCCHERI et alii, 2002). However, in the Naples Gulf the TST is difficult to be defined in terms of thickness and distribution due to the complex interplay among volcanism, tectonics and sedimentary processes (e.g. MILIA, 1998a). So far, the high thickness of the TST deposits in the study area, which reaches the maximum value of about $40 \mathrm{~ms}(30 \mathrm{~m})$, might be related to the input of large amounts of pyroclastic and volcanoclastic materials associated to the NYT eruption and to the subsequent eruptive periods of the Phlegraean Fields (DI VITO et alii, 1999) before the deposition of the HST deposits (from ca. 6.5 cal ka B.P.; AMOROSI et alii, 2012). In particular, volcanoclastic deposits were delivered to the shelf and slope by the fluvial erosion, transportation and depositional system of the Volturno coastal plain where the NYT is found only in correspondence to the morpho-structural highs (AMOROSI et alii, 2012, SACCHI et alii, 2014b). The HST deposits are quite thin if compared with the HST deposits of the adjacent Pozzuoli and Naples gulfs where the active volcanic vents located along the coastline continuously acted as significant sediment sources (pyroclastic, volcanoclastic and epiclastic) to the marine depositional system (e.g. MiLIA, 1998b; AIELlO et alii, 2001; SACCHI et alii, 2005) irrespective of the size of the eruption.

\section{CONCLUSION}


Core data and seismic profiles allowed to recognize and map for the first time the NYT deposits in southern Gaeta Gulf. The data presented in this work point to a relevant role that the NYT deposition had on the stratigraphic architecture and morphological evolution of the study area. According to its wide distribution, it can be considered an excellent marker horizon for the basin and, hence, used as a tool for future stratigraphic, volcanological and marine hazard studies. The NYT is interbedded within the TST succession which has a considerable thickness likely due to the supply of pyroclastic and volcanoclastic deposits related to the intense eruptive activity from the close volcanoes during the Late Pleistocene-Holocene. Undulations and pockmarks are the main morphological features at the sea floor in the study area and they might be mainly related to the intense gas uprising through the TST and HST deposits. The presented results are part of a wider study which currently focuses on the Upper Pleistocene-Holocene evolution of the overall Gaeta Gulf, a pery-Tyrrhenian basin located at mid-position from the Campania Plain eruptive vents.

\section{ACKNOWLEDGMENTS}

The authors wish to thank Roberto Dè Gennaro for his assistance during SEM-EDS acquisition. Biagio Giaccio, Gianni Zanchetta and Roberto Sulpizio are greatly acknowledged for their comments and suggestions that greatly improved the manuscript. This research benefited of grants to M.R.S. from FRA Projects (Sannio University). 


\section{REFERENCES}

Aiello G., Marsella E., SACCHI M. (2000) Quaternary structural evolution of the Terracina and Gaeta basins (Eastern Tyrrhenian margin, Italy). Rend. Lincei, 11, 41-58.

Aiello G., Budillon F., Cristofalo G., D’Argenio B., De Alteris G., De lauro M., Ferraro L., Marsella E., Pelosi N., Sacchi M., Tonielli R. (2001) Marine geology and morphobathymetry in the Bay of Naples (South-Eastern Tyrrhenian sea, Italy). In: FARANDA F.M., Guglielmo L., Spezie G. (Eds.) Structures and Processes of the Mediterranean Ecosystems. Springer-Verlag, Milano, Italy, pp. 1-8.

Aiello G., Cicchella A.G., Di Fiore V., Marsella E.(2011a) New seismo-stratigraphic data of the Volturno Basin (northern Campania, Tyrrhenian margin, southern Italy): implications for tectono-stratigraphy of the Campania and Latium sedimentary basins. Annals of Geophys., 54 (3), 265-283.

Aiello G., Marsella E., Cicchella A.G., Di Fiore V. (2011b) New insights on morphostructures and seismic stratigraphy along the Campania continental margin (Southern Italy) based on deep multichannel seismic profiles. Rend. Lincei, 22, 349-373.

Aiello G., Marsella E., Di Fiore V. (2012) New seismo-stratigraphic and marine magnetic data of the Gulf of Pozzuoli (Naples Bay, Tyrrhenian sea, Italy): inferences for the tectonic and magmatic events of the Phlegrean Fields volcanic complex (Campania). Mar. Geophys. Res., 33 (2), 93-125.

Aiello G., Giordano L., Giordano F. (2016) High resolution seismic stratigraphy of the Gulf of Pozzuoli (Naples Bay) and relationships with submarine volcanic setting of the Phlegrean Fields volcanic complex. Rend. Lincei, accepted article in press., doi: 10.1007/s12210-016-0573-z.

Amorosi A., PACIFICO A., Rossi V., RUBerTi D. (2012) Late Quaternary incision and deposition in an active volcanic setting: the Volturno valley fill, southern Italy. Sed. Geol., 282, 307-320.

Barra D., Romano P., Santo A., Campajola L., Roca V., Tuniz C. (1996) The versilian transgression in the Volturno river plain (Campania, southern Italy): paleoenvironmental history and chronological data. Il Quaternario, 9, 445-458.

Bartole R., Savelli C., Tramontana M., Wezel F.C.(1983) Structural and sedimentary features in the Tyrrhenian margin off Campania, southern Italy. Mar. Geol., 55, 163-180.

Bellotti P. (2000) Il modello morfosedimentario dei maggiori delta tirrenici italiani. Boll. Soc. Geol. It., 119, 777-792.

Bigi G., Cosentino D., Parotto M., Sartori R., Scandone P. (1992) Structural Model of Italy Scale 1:500.000. C.N.R., Progetto Finalizzato Geodinamica, Italy.

Bigi S., Doglioni C., Mariotti G. (2002) Thrust vs normal fault decollements in the Central Apennines. Boll.Soc. Geol. It., Volume Speciale n. 1, 161-166.

Blockley, S.P.E., RAMSEY, C.B., PYLE, D.M. (2008) Improved age modelling and high-precision age estimates of late Quaternary tephras, for accurate palaeoclimate reconstruction. Journal of Volcanology and Geothermal Research 177 (1), 251-262. 
Bonardi G., Amore F.O., Ciampo G., De Capoa P., Miconnet P., Perrone V. (1992) Il Complesso Liguride Auct: stato delle conoscenze e problemi aperti sull'evoluzione preappenninica ed i suoi rapporti con l'Arco Calabro. Mem.Soc. Geol. It., 41, 17-35.

Bourne, A.J., Lowe, J.J., TrincArdi, F., Asioli, A., Blockley, S.P.E., Wulf, S., Matthews, I.P., PIVA, A., VigliotTI, L. (2010) Distal tephra record for the last ca 105,000 years from core PRAD 1-2 in the central Adriatic Sea: implications for marine tephrostratigraphy. Quat. Sc. Rev. 29, 3079-3094.

Bruno P.P., Di Fiore V., Ventura G. (2000) Seismic study of the 41st Parallel Fault System offshore the Campanian-Latial continental margin, Italy. Tectonophys., 324, 37-55.

Buccheri G., Capretto G., Di Donato V., Esposito P., Ferruzza G., Pescatore T., Russo Ermolli E., Senatore M.R., Sprovieri M., Bertoldo M., Carella D., Madonia G. (2002) $A$ high resolution record of the last deglaciation in the southern Tyrrhenian sea: environmental and climatic evolution. Mar. Geol., 186, 447-470.

Budillon F., SEnAtore M.R., Insinga D.D., Iorio M., LubritTo C., RocA M., RuMOlo P. (2012) Late Holocene sedimentary changes in shallow water settings: the case of the Sele river offshore in the Salerno Gulf (south-eastern Tyrrhenian Sea, Italy). Rendi. Lincei, 23 (1), 25-43.

Calanchi, N., Cattaneo, A., Dinelli, E., Gasparotto, G., Lucchini F. (1998) Tephra layers in Late Quaternary sediments of the central Adriatic Sea. Mar. Geol. 149, 191-209.

Capraro L., Massari F., Rio D., Fornaciari E., Backman J., Channell J.E.T., Macrì P., Prosser G., Speranza F. (2011) Chronology of the Lower-Middle Pleistocene succession of the south-western part of the Crotone Basin (Calabria, Southern Italy). Quat. Sc. Rev. 30, 1185-1200

Casciello E., Cesarano M., Pappone G. (2006) Extensional detachment faulting on the Tyrrhenian margin of the southern Apennines contractional belt, (Italy). Journ. of the Geol. Soc. of London, 163, 617-629.

CAtTAneo A., Correggiari A., Trincardi F. (2002) Recognition of turbidite elements in the lateQuaternary Adriatic basin: where are they and what do they tell us? Mediterranean and Black sea Turbidite Systems and Deep Sea Fans. Bucharest 5-8, June 2002.

Cattaneo A.\& Steel R.J. (2003) Transgressive deposits: a review of their variability. Earth Sc. Rev., 62, 187-228.

Catuneanu O., Abreu V., Bhattacharya J.P., Blum M.D., Darlymple R.W., Eriksson P.G., Fielding C.R., Fisher W.I., Galloway W.E., Gibling M.R., Giles K.A., Holbrook J.M., Jordan R., Kendall C.G. St., Macurda B., Martinsen O.J., Miall A.D., Neal J.E., Nummendal D., Pomar L., Posamentier H.W., Pratt B.R., Sarg J.F., Shanley K.W., Steel R.J., Strasser A., TUCKer M.E., WINKER C. (2009) Towards the standardization of sequence stratigraphy. Earth Sci. Rev., 92, 1-33.

Chappell J. \& Shackleton N.J. (1986) Oxygen isotopes and sea level. Nature, 324, 137-140.

ChIOcCi F.L. \& CASAlBore D. (2011) Submarine gullies on Italian upper slopes and their relationship with volcanic activity revisited 20 years after Bill Normark's pioneering work. Geosphere, 7 (6), 1284-1293.

Cinque A., Irollo G., Romano P., Ruello M.R., Amato L., Giampaola D. (2011) Ground movements and sea level changes in urban areas: 5000 years of geological and archeological record from Naples (southern Italy). Quat. Int., 232, 45-55.

16 
Coppa M.G., Ferraro L., Pennetta M., Russo B., Valente A., Vecchione C. (1996) Sedimentology and micropaleontology of the core G39-C27 (Gaeta bay, central Tyrrhenian Sea, Italy). Il Quaternario, 9 (2), 687-696.

Correggiari A., Trincardi F., Langone L., Roveri M. (2001) Styles of failure in late holocene highstand prodelta wedges on the adriatic shelf. J Sedim Res 71(2), 218-236. doi:10.1306/042800710218

De Alteris G., Insinga D.D., Morabito S., Morra V., Chiocci F.L., Terrasi F., Lubritto C., Di Benedetto C., PAZzAnese M. (2010) Age of submarine debris avalanches and tephrostratigraphy offshore Ischia island, Tyrrhenian sea, Italy. Mar. Geol., 278, 1-18.

Deino A.L., Orsi G., Piochi M., De Vita S. (2004) The age of the Neapolitan Yellow Tuff calderaforming eruption (Campi Flegrei caldera - Italy) assessed by 40Ar/39Ar dating method. Journ. of Volcanol. and Geoth. Res., 133, 157-170.

De Vivo B., Rolandi G., Gans P.B., Calvert A., Bohrson W.A., Spera F.J., Belkin H.E. (2001) New constraints on the pyroclastic eruptive history of the Campanian volcanic plain (Italy). Mineral. and Petrol., 73, 47-65.

Di Vito M.A., Isaia R., Orsi G., Southon J., De Vita S., D’Antonio M., Pappalardo L., Piochi M. (1999) Volcanism and deformation since 12.000 years at the Campi Flegrei caldera (Italy). Journ. of Volcanol. and Geoth. Res., 91, 221-246.

Di Vito, M., Sulpizio, R., Zanchetta, R., D’Orazio, M. (2008) The late Pleistocene pyroclastic deposits of the Campanian Plain: new insights on the explosive activity of Neapolitan volcanoes. Journ. of Volcanol. and Geoth. Res. 177, 19-48.

Duvail C., Gorinib C., Lofi J., Le Strata P., Clauzond G., Dos Reise A.T. (2005) Correlation between onshore and offshore Pliocene-Quaternary systems tracts below the Roussillon Basin (eastern Pyrenees, France). Marine and Petroleum Geology, 22, 747-756.

ERCIlla G., Alonso B., BARAZA J. (1994) Post-calabrian sequence stratigraphy of the northwestern Alboran Sea (southwestern Mediterranean). Mar Geol 120 (3-4), 249-265. doi:10.1016/ 0025-3227(94)90061-2

ERCIlla G., DìAZ J.I., Alonso B., FARRAn M. (1995) Late pleistocene- holocene sedimentary evolution of the northern Catalonia continental shelf (northwestern Mediterranean Sea). Cont. Shelf. Res. 15(11-12), 1435-1451. doi:10.1016/0278-4343(94)00089-6

FabBri A., Gallignani P., Zitellini N. (1981) Geological evolution of the perityrrhenian sedimentary basins. In: WEZEL F.C. (Ed.) Sedimentary basins of the Mediterranean margins. Tecnoprint, Bologna, Italy.

Fabbri A., Argnani A., Bortoluzzi G., Correggiari A., Gamberi F., Ligi M., Marani M., Penitenti D., Roveri M., TRINCARDI F. (2002) Linee guida al rilevamento geologico dei mari italiani. Pres. Cons. Min., Quaderno 8.

Florio G., Fedi M., Cella F., Rapolla A. (1999) The Campanian Plain and Phlegrean Fields: structural setting from potential field data. Journ. of Volcanol. and Geoth. Res., 91 (2/4), 361-379.

HunT D. \& TUCKER M.E. (1992) Stranded parasequences and the forced regressive wedge system tract deposition during base-level-fall. Sed. Geol., 81, 1-9. 
Insinga D.D., Molisso F., Lubritto C., SACChi M., PASSARiello L., Morra V. (2008) The proximal marine record of Somma-Vesuvius volcanic activity in the Naples and Salerno bays, Eastern Tyrrhenian sea, during the last 3 kyrs. Journ. of Volcanol. and Geoth. Res., 177, 170-186.

Insinga D.D., Tamburrino S., Lirer F., Vezzoli L., Barra M., De Lange G.J., Tiepolo M., VAllefuoco M., Mazzola S., Sprovieri M. (2014) Tephrochronology of the astronomicallytuned KC01B deep-sea core, Ionian Sea: insights into the explosive activity of the Central Mediterranean area during the last $200 \mathrm{ka}$. Quat. Sc. Rev., 85, 63-84.

Iorio M., Sagnotti L., Angelino A., Budillon F., D’Argenio B., Dinares-Turell J., Macrì P., MARSELla E. (2004) High resolution petrophysical and palaeomagnetic study of Late Holocene shelf sediments, Salerno Gulf, Tyrrhenian Sea. The Holocene, 14 (3), 426-425.

Iorio M., Liddicoat J., Budillon F., InCOROnato A., CoE R.S., Insinga D.D., Cassata W., Lubritto C., ANGElino A., TAMBuRRINo S. (2014a) Combined palaeomagnetic secular variation and petrophysical records to time-constrain geological and hazardous events: an example from the eastern Tyrrhenian Sea in the last $120 \mathrm{ka}$. Global and Plan. Change, 113, 91-109.

Iorio M., Capretto G., Petruccione E., Marsella E., Aiello G., Senatore M.R. (2014b) Multi-proxy analysis in defining sedimentary processes in very recent prodelta deposits: the northern Phlegrean offshore example (Eastern Tyrrhenian margin). Rendi. Lincei, 25 (2), 237-254.

Lane C.S., Brauer A., Marta An-Puertas C., Blockley S.P.E, Smith V.C., Tomlinson E.L., (2015) The Late Quaternary tephrostratigraphy of annually laminated sediments from Lake Meerfelder Maar, Germany. Quat. Sci. Rev., 122, 192-206.

Lambeck, K., Chappell, J., (2001) Sea-level change through the last glacial cycle. Science, 292, 679-686.

Lambeck, K., Rouby, H., Purcell, A., Sun, Y., \& SAmbridge, M. (2014). Sea level and global ice volumes from the Last Glacial Maximum to the Holocene. Proceedings of the National Academy of Sciences, 111(43), 15296-15303.

Le MAITRE R.W. 2005. Igneous Rocks. A Classification and Glossary of Terms. Recommendations of the International Union of Geological Sciences Subcommission on the Systematics of Igneous Rocks. Cambridge University Press, Cambridge.

Lykousis V., Sakellariou D., Roussakis G. (2003) Prodelta slope stability and associated coastal hazards in tectonically active margins: Gulf of Corinth (NE Mediterranean). In: Locat J, Mienert J (eds) Submarine mass movements and their consequences. Kluwer Academic Publishers, pp 433-440

Lirer F., Sprovieri M., Ferraro L., Vallefuoco M., Capotondi L., Cascella A., Petrosino P., Insinga D.D., Pelosi N., TAmburrino S., Lubritto C. (2013) Integrated stratigraphy in the eastern Tyrrhenian sea. Quat. Int., 292, 71-85.

LisIECKI L.E., RAYMO M.E. (2005) A Pliocene-Pleistocene stack of 57 globally distributed benthic D18O records. Paleoceanography, VOL. 20, PA1003, doi:10.1029/2004PA001071, 2005.

lofi J., Rabineauc M., Gorinid C., Berne S., Clauzon G., De Clarens P., Dos Reise A.T., Mountain G.S., Ryan W.B.F., SteCKLeR M.S., Foucheta C. (2003) Plio-Quaternary prograding clinoform wedges of the western Gulf of Lion continental margin (NW Mediterranean) after the Messinian Salinity Crisis. Marine Geology, 198 (3-4), 289-317.

Lowe D.J. (2011) Tephrochronology and its application: a review. Quat. Geochronol., 6, 107-153. 18 
MALINVERNO A. \& RYAN W.B.F. (1986) Extension in the Tyrrhenian Sea and shortening in the Apennines as result of arc migration driven by sinking of the lithosphere. Tectonics, 5 (2), 227-245.

Marani M., TAViani M., Trincardi F., Argnani A. (1986) Pleistocene progradation and postglacial events of the NE Tyrrhenian continental shelf between the Tiber river delta and Capo Circeo. Mem. Soc. Geol. It., 36, 67-89.

Margaritelli G., Vallefuoco M., Di Rita F., Capotondi L., Bellucci L.G., Insinga D.D., Petrosino P., Bonomo S., Cacho I., Cascella A., Ferraro L., Florindo F., Lubritto C., Lurcock P.C., Magri D., Pelosi N., RetTori R., LiRer F. (2016) Marine response to climate changes during the last five millennia in the central Mediterranean Sea. Global and Plan. Change, 142, 53-72.

MARIANI M. \& PRAto R. (1988) I bacini neogenici costieri del margine tirrenico. Approccio sismico-stratigrafico. Mem. Soc. Geol. It., 41, 519-531.

MARTORELli E., CHIOCCI F.L., ORLANDO L. (2010) Imaging continental shelf shallow stratigraphy by using different high resolution seismic sources: an example from the Calabro-Tyrrhenian margin (Mediterranean sea). Braz. Journ. of Oceanogr., 58(1) http://dx.doi.org/10.1590/S167987592010000500006.

MAselli V. \& TRInCARDi F. (2013) Man made deltas. Scientific Reports, 3, 1926 doi:10.1038/srep01926.

Milia A., (1998a) Le unità piroclastiche tardo-quaternarie del Golfo di Napoli, Geogr. Fis. Dinam. Quat., 21, 147-153.

Milia A. (1998b) Stratigrafia, strutture deformative e considerazioni sull'origine delle unità deposizionali oloceniche del Golfo di Pozzuoli (Napoli). Boll. Soc. Geol. It., 117, 777-787.

Maselli, V., Trincardi, F., Asioli, A., Ceregato, A., Rizzetto, F., Taviani, M. (2014) Delta growth and river valleys: The influence of climate and sea level changes on the South Adriatic shelf (Mediterranean Sea). Quat. Sc. Rev., 99, 146-163.

Milia A. \&TORRENTE M.M. (2015) Tectono-stratigraphic signature of a rapid multistage subsiding rift basin in the Tyrrhenian-Apennine hinge zone (Italy): A possible interaction of upper plate with subducting slab. Journ. of Geodyn., 86, 42-60.

Milia A., Raspini A., Torrente M.M. (2007) The dark nature of Somma-Vesuvius volcano: evidence from the $3.5 \mathrm{ka}$ B.P. Avellino eruption. Quat. Int., 173/174, 57-66.

Milia A., Molisso F., Raspini A., SaCchi M., Torrente M.M. (2008) Syneruptive features and sedimentary processes associated with pyroclastic currents entering the sea: the AD79 eruption of Vesuvius, Bay of Naples, Italy. Journ. of the Geol. Soc. of London, 165, 839-848.

Milia A., Torrente M.M., Massa B., IAnnace P. (2013) Possible changes in rifting directions in the Campania margin (Italy): New constrains for the Tyrrhenian sea opening. Global and Plan. Change, 109, 3-17.

MitchUM R.M. \& VAIL P.R. (1977) Seismic stratigraphy and global changes of sea level, part 7: stratigraphic interpretation of seismic reflection patterns in depositional sequences. In: PAYTON C.E. (Ed.) Seismic Stratigraphy - Applications to Hydrocarbon Exploration. Memoir 26, American Association of Petroleum Geologists, pp. 135-144. 
Morabito, S., Petrosino, P., Milia, A., Sprovieri, M., Tamburrino, S. (2014) A multidisciplinary approach for reconstructing the stratigraphic framework of the last $40 \mathrm{ka}$ in a bathial area of the eastern Tyrrhenian Sea. Global Planet. Change 123, 121-138.

Orsi G., D’Antonio M., DE Vita S \& GAllo G. (1992) The Neapolitan Yellow Tuff, a largemagnitude trachytic phreato-plinian eruption; eruptive dynamics, magma withdrawal and caldera collapse, J. Volcanol. Geotherm. Res, 53, 275-287.

Orsi G, Civetta L, D’Antonio M, Di Girolamo P, Piochi M (1995) Step-filling and development of a three-layers magma chamber: the Neapolitan Yellow Tuff case history. J. Volcanol. Geotherm. Res 67, 291-312.

Paterne, M., Guichard, F., Labeyrie, J., Gillot, P.Y., Duplessy, J.C. (1986) Tyrrhenian Sea tephrochronology of the oxygen isotope record for the past 60.000 years. Mar. Geol. 72, 259-285.

Pellegrini C., Maselli V., Cattaneo A., Piva A., Ceregato A., Trincardi F. (2010) Anatomy of a compound delta from the post-glacial transgressive record in the Adriatic Sea. Mar. Geol., 362, 43-59.

Petruccione E., Aiello G., Capretto G., Senatore M.R., Marsella E., Iorio M. (2011) Holocene sedimentary and gravitative processes in highstand prodelta deposits on the Cuma outer shelf (Eastern Tyrrhenian sea): an integrated approach. DTA6/2011, CNR, Dipartimento Terra e Ambiente, 771-784.

Rolandi G., Bellucci F., Heizler M.T., BelKin H.E., De Vivo B. (2003) Tectonic controls on the genesis of ignimbrites from the Campanian Volcanic Zone, southern Italy. Mineral. and Petrol., 79, 3-31.

Romano P., Santo A., Voltaggio M. (1994) L'evoluzione geomorfologica della pianura del fiume Volturno (Campania) durante il tardo Quaternario (Pleistocene medio-superiore-Olocene). Il Quaternario, 7 (1), 41-56.

Rosi M. \& Sbrana A. (1987) Phlegrean Fields, C.N.R., Quaderni de "La ricerca scientifica”, 1149, pp176.

Sacchi M., Insinga D., Milia A., Molisso F., Raspini A., Torrente M.M., Conforti A. (2005) Stratigraphic signature of the Vesuvius 79 AD event off the Sarno prodelta system, Naples Bay. Marine Geol., 222-223, 443-469.

Sacchi M., Molisso F., Violante C., Esposito E., Insinga D.D., Lubritto C., Porfido S., Toth T. (2009) Insights into flood-dominated fan-deltas: very high resolution seismic examples off the Amalfi cliffed coasts, eastern Tyrrhenian sea. Geol. Soc. of London, Spec. Publ., 322, 33-71.

Sacchi M., Pepe F., Corradino M., Insinga D.D., Molisso F., Lubritto C. (2014a) The Neapolitan Yellow Tuff caldera offshore the Campi Flegrei: Stratal architecture and kinematic reconstruction during the last $15 \mathrm{ky}$. Marine Geol., 354, 15-33.

Sacchi M., Molisso F., Pacifico A., Vigliotti M., Sabbarese C., Ruberti D. (2014b) LateHolocene to recent evolution of Lake Patria, South Italy: An example of a coastal lagoon within a Mediterranean delta system. Global and Plan. Change, 117, 9-27.

Scarpati C., Cole P., Perrotta A. (1993) The Neapolitan Yellow Tuff - a large volume multiphase eruption from Campi Flegrei, Southern Italy. Bull. Volcanol., 55, 343-356. 
Siani, G., Sulpizio, R., PAterne, M., Sbrana, A. (2004) Tephrostratigraphy study for the last $18.000{ }^{14}$ C years in a deep-sea sediment sequence of the South Adriatic. Quat. Sc. Rev. 23, 24852500 .

Smith V.C., IsAia R., PeARCE N.J.G. (2011) Tephrostratigraphy and glass compositions of post 15kyr Campi Flegrei eruptions: implications for eruption history and chronostratigraphic markers. Quat. Sci. Rev., 30, 3638-3660.

Tomlinson E.L., Arienzo I., Wulf S., Smith V.C., Carandente A., Civetta L., Hardiman M., Lane C.S., Orsi G., Rosi M., Thirlwall M.T., Muller W., Menzies M.A. (2012) Geochemistry of the Phlegraean Fields (Italy) proximal sources for major Mediterranean tephras: implications for the dispersal of Plinian and co-ignimbritic components of explosive eruptions. Geochim. Cosmochim. Acta 93, 102-128. doi:10.1016/j.gca.2012.05.043

TORRENTE M.M. \& Milia A. (2013) Volcanism and faulting of the Campania margin (Eastern Tyrrhenian sea, Italy): a three-dimensional visualization of a new volcanic field off Campi Flegrei. Bull. of Volcanol., 75-719, doi 10.1007/s00445-013-0719-0.

TRINCARDi F., CORREgGiari A., ROVERI M. (1994) Late Quaternary trasgressive erosion and deposition in a modern epicontinental shelf: the Adriatic semi-enclosed basin. Geomarine Letters, 14, 41-51.

TRINCARDI F., NORMARK W. (1988) Sediment waves on the Tiber prodelta slope: interaction of deltaic sedimentation and currents along the shelf. Geo-Mar Lett. 8(3):149-157. doi:10.1007/bf02326091

VAIL P.R., Mitchum R.M., ThOMPSOn S. (1977) Seismic stratigraphy and global changes of sea level, part 3: relative changes of sea level from coastal onlap. In: PAYTON C.E. (Ed.) Seismic Stratigraphy - Applications to Hydrocarbon Exploration. Memoir vol. 26, American Association of Petroleum Geologists, pp. 63-81.

Van Wagoner J.C., Posamentier H.W., Mitchum R.M., Vail P.R., Sarg J.F., Loutit T.S., HARDENBOL J. (1988) An overview of sequence stratigraphy and key definitions. In: Wilgus C.K., Hastings B.S., Kendall C.G. St. C., Posamentier H.W., Ross C.A., Van Wagoner J.C. (Eds.) Sea level. Changes- an integrated approach. SEPM Special Publication, 42, 39-45.

Zanchetta, G., Sulpizio, R., Roberts, N., Cioni, R., Eastwood, W.J., Siani, G., Caron, B., PATERne, M., SANTACROCE, R., 2011. Tephrostratigraphy, chronology and climatic events of the Mediterranean basin during the Holocene: An overview. The Holocene 21(1), 33 -52.

ZECCHIN M. \& CATUNEANU O. (2013) High-resolution sequence stratigraphy of clastic shelves I: Units and bounding surfaces. Mar. and Petrol. Geol., 39, 1-25. 


\section{FIGURE CAPTIONS}

Fig. 1: Location of the study area in the northern Phlegraean Fields offshore, along the eastern Tyrrhenian margin. The seismic lines and the C1161 core used in this study are reported.

Figure 2. (I) Grain size, (II) Lithology and (III) Raw Volume Magnetic susceptibility logs of core C1161. Black star and label $V$ indicate the stratigraphic height of tephra sample and the top of the volcanic marker, respectively (modified from Iorio et al 2014).

Fig. 3: a) TAS (Total Alkali/Silica) classification diagram (Le Maitre, 2005) of C1161/1 tephra. b) $\mathrm{FeO}$ vs $\mathrm{SiO}_{2}$ and c) $\mathrm{CaO}$ vs $\mathrm{SiO}_{2}$ variation diagrams with composition of the analysed tephra. Single glass data (WDS) of the NYT proximal deposits (Upper Member and Lower Member) are reported for comparison (from Tomlinson et al., 2012).

Fig. 4: ChirpProfile (trasf_0; modified from Iorio et al., 2014b) showing the seismo-stratigraphic architecture of the area (see location in Fig. 1). Notice the volcanic marker (V) marked in red. See text for explanation.

Fig. 5: Chirp Profiles M196, M197 and M198 (see location in Fig. 1). Notice the volcanic marker (V) marked in red. See text for the explanation.

Fig. 6: Chirp Profiles M198A (modified from Iorio et al., 2014b), M199 and M200 (see location in Fig. 1). Notice the volcanic marker (V) marked in red. See text for the explanation.

Fig. 7: Map of the depth trend of the $V$ reflector (NYT) from the sealevel. The colorimetric scale represents the variation of the depth in milliseconds with the corresponding values in meters. The inset on the top right shows a 3D model of the NYT trend.

Figure 8: Map of the depth trend of the $V$ reflector (NYT) from the seafloor. The colorimetric scale represents the variation of the depth in milliseconds with the corresponding values in meters. The inset on the top right shows a 3D model of the NYT trend.

22

https://mc.manuscriptcentral.com/ijg 


\section{TABLE CAPTIONS}

Table1: Location, orientation and average water-depths details of the analyzed Subbottom Chirp lines.

Table 2: Major element content of single glass (wt. \%) in sample C1161/1. All analyses are recalculated water-free to 100 . 


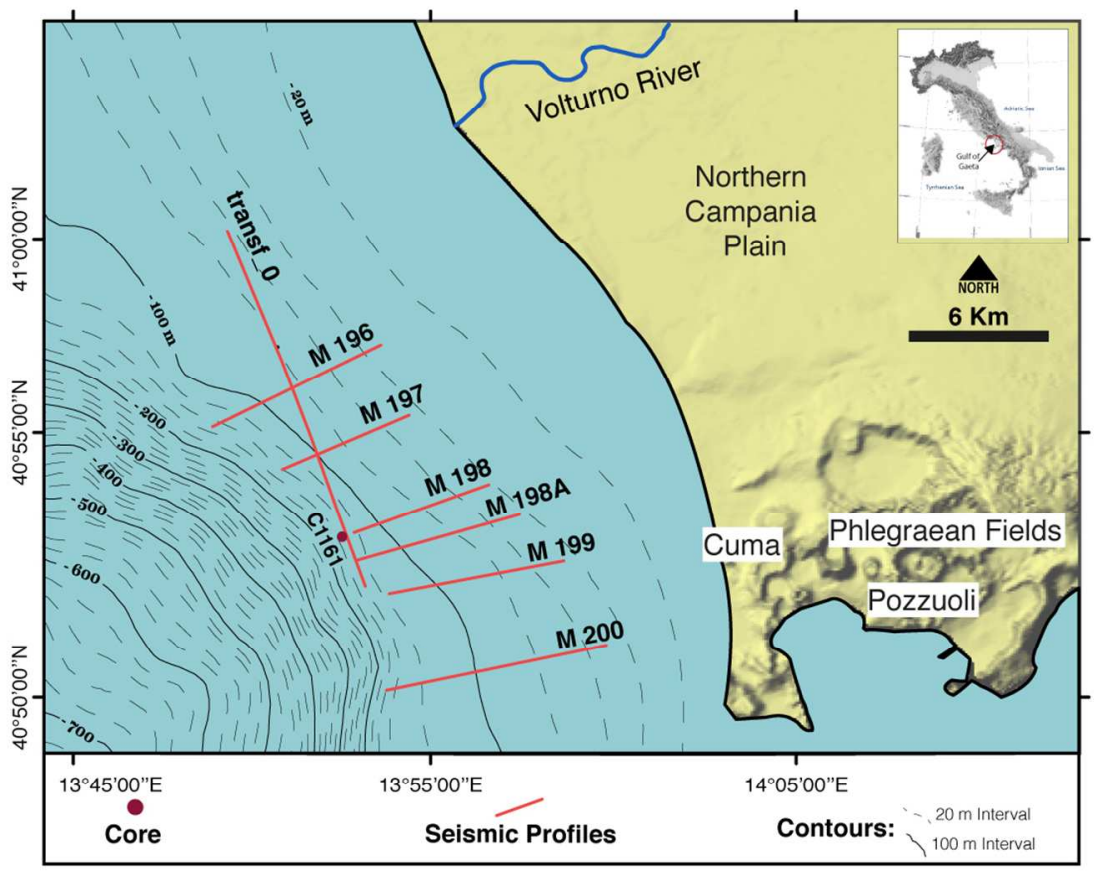

Figure 1: Location of the study area in the northern Phlegraean Fields offshore, along the eastern Tyrrhenian margin. The seismic lines and the C1161 core used in this study are reported.

$$
111 \times 80 \mathrm{~mm}(300 \times 300 \text { DPI) }
$$




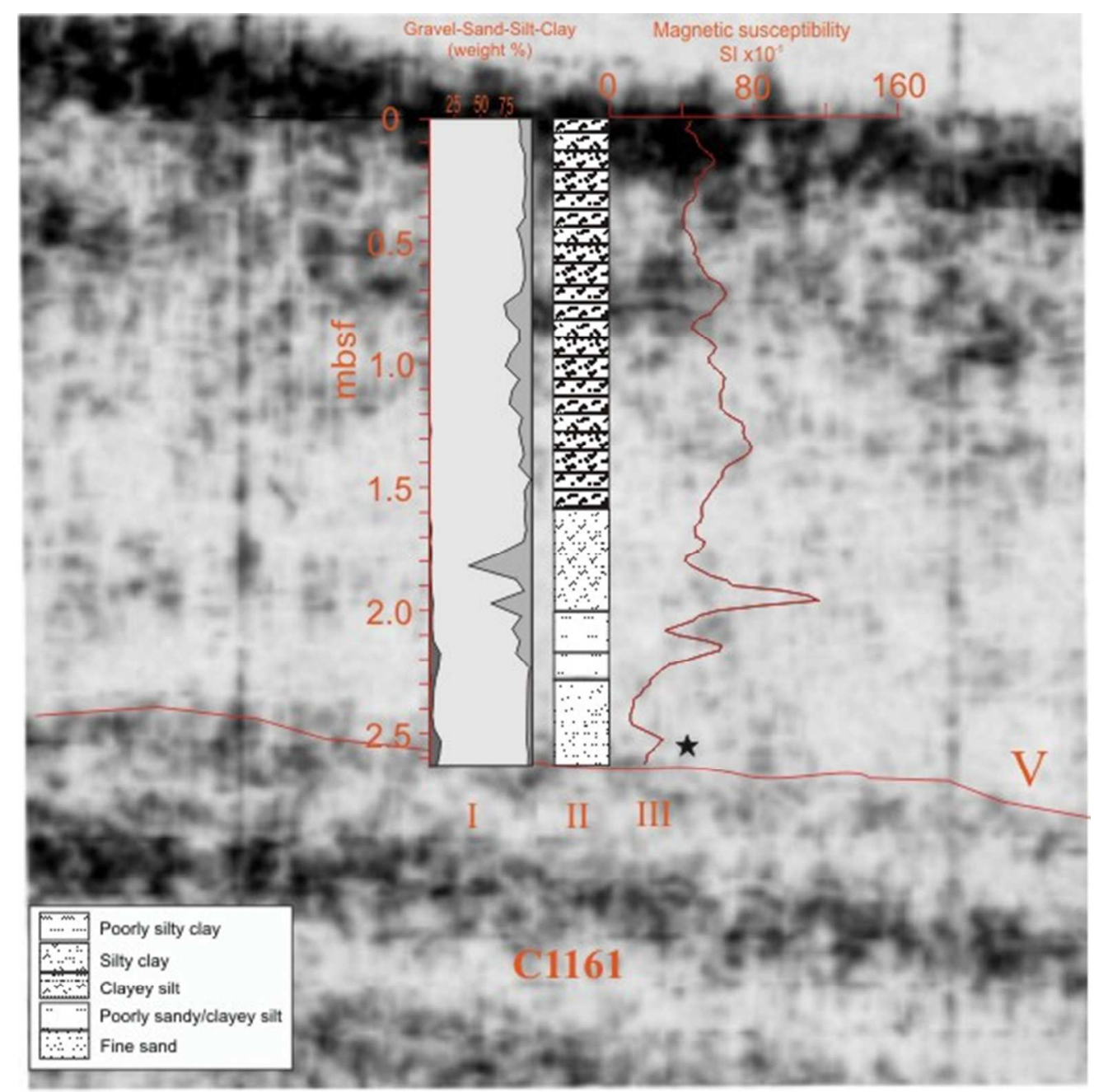

Figure 2. (I) Grain size, (II) Lithology and (III) Raw Volume Magnetic susceptibility logs of core C1161. Black star and label $\mathrm{V}$ indicate the stratigraphic height of tephra sample and the top of the volcanic marker, respectively (modified from Iorio et alii, 2014b).

$145 \times 146 \mathrm{~mm}(100 \times 100 \mathrm{DPI})$ 

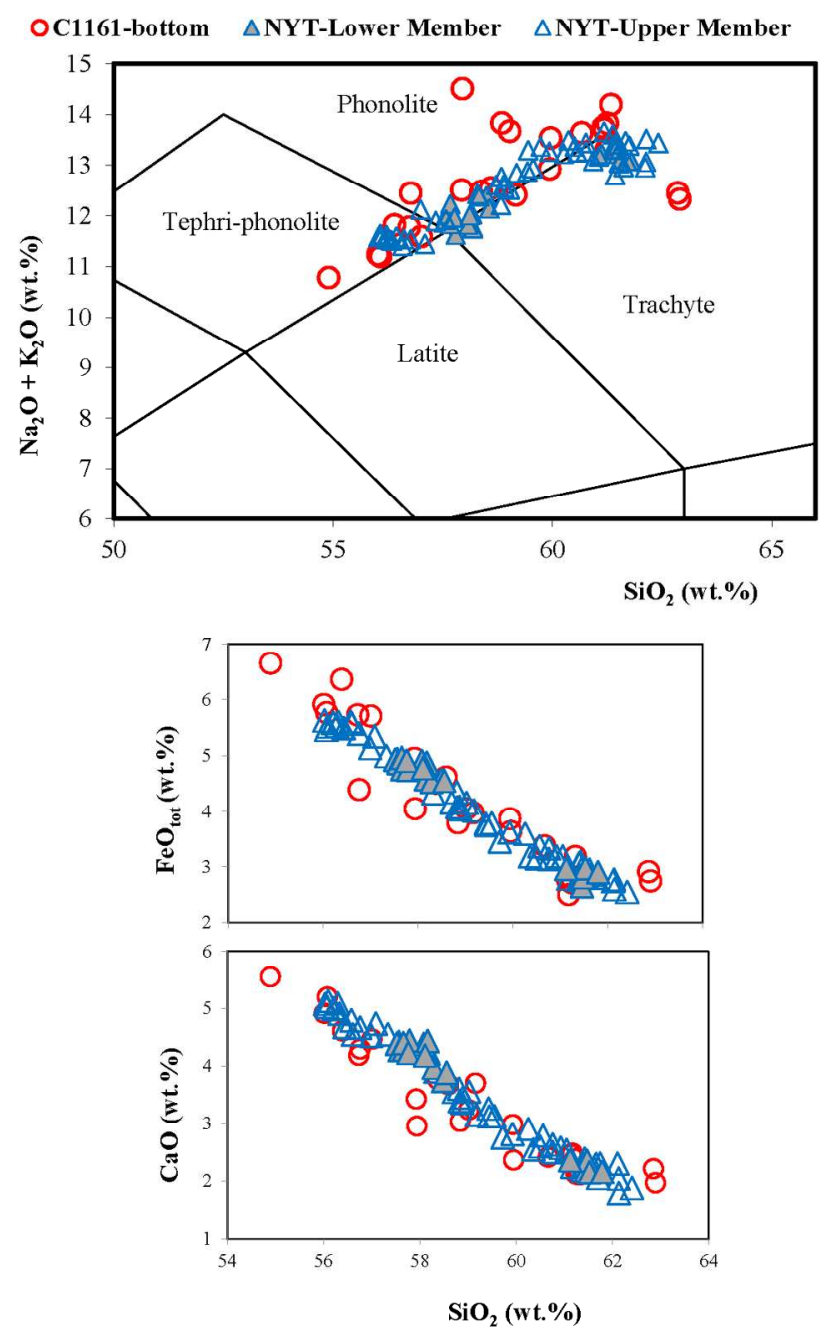

Figure 3: a) TAS (Total Alkali/Silica) classification diagram (Le Maitre, 2005) of C1161/1 tephra. b) FeO vs $\mathrm{SiO} 2$ and c) $\mathrm{CaO}$ vs $\mathrm{SiO} 2$ variation diagrams with composition of the analysed tephra. Single glass data (WDS) of the NYT proximal deposits (Upper Member and Lower Member) are reported for comparison (from Tomlinson et alii, 2012).

$$
210 \times 297 \mathrm{~mm}(200 \times 200 \text { DPI })
$$




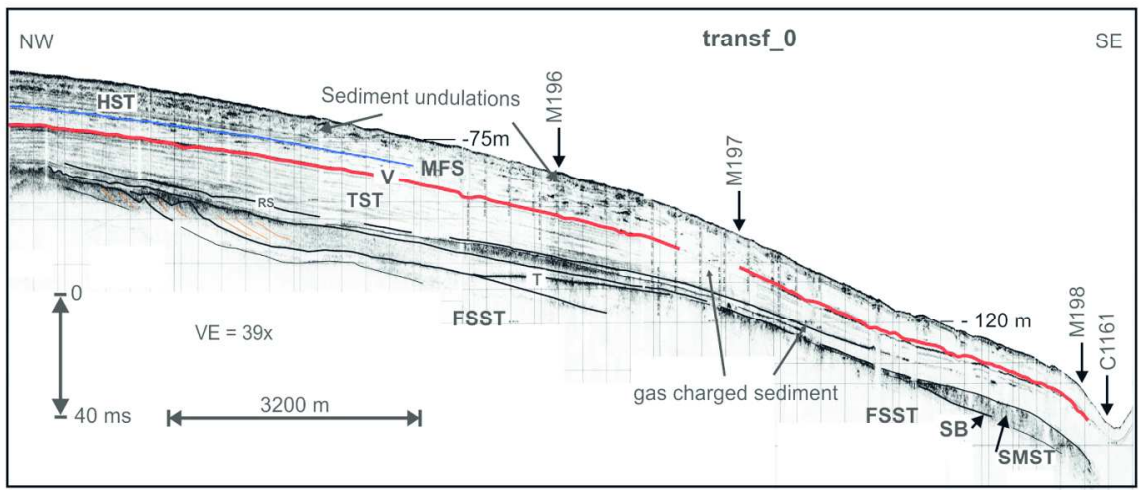

Figure 4: ChirpProfile (trasf_0; modified from Iorio et alii, 2014b) showing the seismo-stratigraphic architecture of the area (see location in Fig. 1). Notice the volcanic marker (V) marked in red. See text for explanation.

$199 \times 150 \mathrm{~mm}(300 \times 300 \mathrm{DPI})$ 


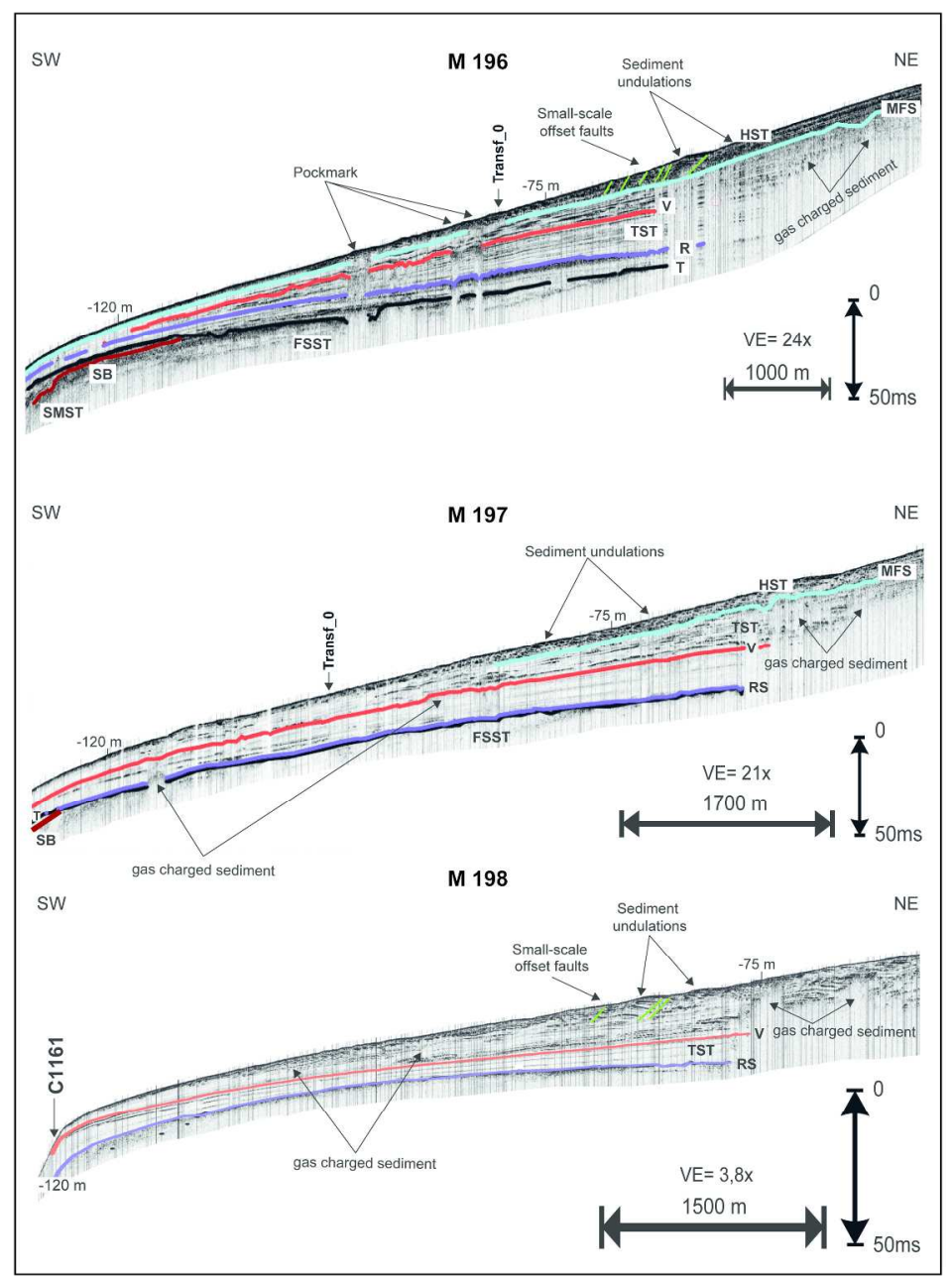

Figure 5: Chirp Profiles M196, M197 and M198 (see location in Fig. 1). Notice the volcanic marker (V) marked in red. See text for the explanation.

$$
214 \times 300 \mathrm{~mm}(300 \times 300 \mathrm{DPI})
$$


Figure 6: Chirp Profiles M198A (modified from Iorio et alii, 2014b), M199 and M200 (see location in Fig. 1). Notice the volcanic marker $(\mathrm{V})$ marked in red. See text for the explanation.

$$
214 \times 300 \mathrm{~mm}(300 \times 300 \mathrm{DPI})
$$


Figure 7: Map of the depth trend of the $\mathrm{V}$ reflector (NYT) from the sealevel. The colorimetric scale represents the variation of the depth in milliseconds with the corresponding values in meters. The inset on the top right shows a 3D model of the NYT trend.

$$
300 \times 214 \mathrm{~mm}(300 \times 300 \text { DPI) }
$$


Figure 8: Map of the depth trend of the $\mathrm{V}$ reflector (NYT) from the seafloor. The colorimetric scale represents the variation of the depth in milliseconds with the corresponding values in meters. The inset on the top right shows a 3D model of the NYT trend.

$$
300 \times 214 \mathrm{~mm}(300 \times 300 \text { DPI })
$$


TAB 1

\begin{tabular}{|l|l|l|l|}
\hline $\begin{array}{l}\text { Seismic } \\
\text { line }\end{array}$ & Orientation & Location & $\begin{array}{l}\text { Average } \\
\text { water depths }\end{array}$ \\
\hline M200 & WNW-ESE & $\begin{array}{l}\text { Southern Tyrrhenian sea,extending from the } \\
\text { Torregaveta offshore (WNW) to the Tyrrhenian sea } \\
\text { northwards Ischia island (ESE) }\end{array}$ & $\begin{array}{l}18 \mathrm{~m} \text { (WNW) } \\
435 \mathrm{~m} \text { (ESE) }\end{array}$ \\
\hline M199 & WNW-ESE & $\begin{array}{l}\text { Southern Tyrrhenian sea, extending from the Cuma } \\
\text { offshore (WNW) to the Tyrrhenian sea (ESE) }\end{array}$ & $\begin{array}{l}22 \mathrm{~m} \text { (WNW) } \\
400 \mathrm{~m}(\mathrm{ESE})\end{array}$ \\
\hline M198A & WNW-ESE & $\begin{array}{l}\text { Southern Tyrrhenian sea, extending from the Licola } \\
\text { offshore (WNW) to the Tyrrhenian sea (ESE) }\end{array}$ & $\begin{array}{l}16 \mathrm{~m} \text { (WNW) } \\
250 \mathrm{~m} \text { (ESE) }\end{array}$ \\
\hline M198 & WNW-ESE & $\begin{array}{l}\text { Southern Tyrrhenian sea, extending from the Patria } \\
\text { Lake offshore (WNW) to the Tyrrhenian sea (ESE) }\end{array}$ & $\begin{array}{l}17 \mathrm{~m} \text { (WNW) } \\
400 \mathrm{~m}(\mathrm{ESE})\end{array}$ \\
\hline M197 & WNW-ESE & $\begin{array}{l}\text { Southern Tyrrhenian sea, extending from the } \\
\text { Ischitella offshore (WNW) to the Tyrrhenian sea } \\
\text { (ESE) }\end{array}$ & $\begin{array}{l}18 \mathrm{~m} \text { (WNW) } \\
320 \mathrm{~m} \text { (ESE) }\end{array}$ \\
\hline TRANS0 & S-N & $\begin{array}{l}\text { Southern Tyrrhenian sea, extending from the Cuma } \\
\text { offshore (S) to the Ischitella offshore (N) }\end{array}$ & $\begin{array}{l}120 \mathrm{~m} \text { (S) 22 } \\
\mathrm{m} \text { (N) }\end{array}$ \\
\hline
\end{tabular}




\begin{tabular}{|c|c|c|c|c|c|c|c|c|c|c|c|c|c|c|c|c|c|c|c|c|c|c|c|c|c|}
\hline tephra/sample & & & & & & & & & & & & & $1161 / 1$ & & & & & & & & & & & & \\
\hline$\overline{\mathrm{SiO}_{2}}$ & 56.03 & 60.83 & 58.01 & 57.57 & 55.67 & 55.75 & 56.71 & 57.56 & 59.56 & 60.85 & 60.85 & 60.79 & 58.81 & 56.51 & 59.55 & 60.75 & 58.61 & 58.42 & 56.38 & 54.60 & 60.16 & 58.22 & 62.43 & 62.47 & 60.73 \\
\hline $\mathrm{TiO}_{2}$ & 0.28 & 0.50 & 0.53 & 0.42 & 0.77 & 0.44 & 0.34 & 0.86 & 0.54 & 0.35 & 0.43 & 0.58 & 0.67 & 0.60 & 0.55 & 0.14 & 0.53 & 0.65 & 0.43 & 0.85 & 0.63 & 0.23 & 0.54 & 0.45 & 0.36 \\
\hline $\mathrm{Al}_{2} \mathrm{O}_{3}$ & 18.01 & 18.90 & 18.60 & 19.13 & 18.18 & 18.19 & 18.25 & 18.0 & 18.60 & 18.57 & 18.81 & 18.85 & 18.34 & 18.94 & 18.26 & 18.75 & 18.76 & 18.48 & 18.33 & 18.23 & 1826,0 & 18.83 & 18.28 & 18.28 & 18.50 \\
\hline FeOtot & 6.32 & 2.69 & 4.48 & 4.02 & 5.88 & 5.74 & 5.68 & 4.92 & 3.1 & 3.16 & 2.79 & 2.48 & 3.95 & 4.37 & 3.84 & 2.74 & 4.02 & 3.77 & 5.69 & 6.62 & 3.3 & 4.58 & 2.72 & 2.89 & 2.79 \\
\hline $\mathrm{MnO}$ & 0.26 & 0.17 & 0.10 & 0.22 & 0.25 & 0.56 & 0.31 & 0.10 & 0.28 & 0.36 & 0.00 & 0.07 & 0.15 & 0.62 & 0.23 & 0.45 & 0.00 & 0.23 & 0.16 & 0.12 & 0.13 & 0.00 & 0.59 & 0.14 & 0.45 \\
\hline $\mathrm{MgO}$ & 1.64 & 0.38 & 1.24 & 0.59 & 1.99 & 2.05 & 1.68 & 1.10 & 0.79 & 0.37 & 0.53 & 0.41 & 1.29 & 1.49 & 0.80 & 0.37 & 0.59 & 0.75 & 1.79 & 2.36 & 0.64 & 1.18 & 0.31 & 0.42 & 0.27 \\
\hline СaO & 4.58 & 2.10 & 3.75 & 2.93 & 4.88 & 5.17 & 4.44 & 3.41 & 2.35 & 2.08 & 2.37 & 2.46 & .68 & 4.28 & 2.96 & 2.44 & 3.22 & 3.01 & 4.16 & 5.52 & 2.39 & 3.66 & 1.95 & 2.19 & 1.68 \\
\hline $\mathrm{Na}_{2} \mathrm{O}$ & 3.45 & 4.52 & 3.56 & 4.22 & 3.53 & 3.27 & 3.36 & 3.62 & 3.82 & 5.78 & 4.43 & 4.27 & 3.53 & 3.72 & 4.22 & 4.25 & 3.81 & 3.90 & 3.57 & 3.38 & 4.75 & 3.77 & 4.31 & 3.82 & 6.63 \\
\hline $\mathrm{K}_{2} \mathrm{O}$ & 8.29 & 9.21 & 8.85 & 10.19 & 7.63 & 7.86 & 8.18 & 8.81 & 9.63 & 7.53 & 8.79 & 9.36 & 8.80 & 8.67 & 8.63 & 9.41 & 9.77 & 9.83 & 8.13 & 7.35 & 8.78 & 8.70 & 7.93 & 8.56 & 7.43 \\
\hline $\mathrm{P}_{2} \mathrm{O}_{5}$ & 0.49 & 0.0 & 0.27 & 0.05 & 0.59 & 0.38 & 0.52 & 0.49 & 0.16 & 0.18 & 0.38 & 0.09 & 0.17 & 0.36 & 0.31 & 0.03 & 0.00 & 0.24 & 0.73 & 0.44 & 0.07 & 0.18 & 0.20 & 0.16 & 0.17 \\
\hline $\mathrm{Cl}$ & 0.64 & 0.69 & 0.61 & 0.65 & 0.62 & 0.59 & 0.53 & 0.63 & 0.65 & 0.76 & 0.61 & 0.63 & 0.60 & 0.45 & 0.63 & 0.66 & 0.7 & 0.71 & 0.62 & 0.54 & 0.84 & 0.64 & 0.75 & 0.62 & 0.98 \\
\hline Original Total & 100.53 & 101.09 & 98.72 & 99.45 & 97.71 & 97.36 & 97.76 & 98.84 & 97.90 & 96.04 & 96.26 & 97.18 & 101.57 & 99.60 & 101.91 & 99.04 & 94.98 & 99,3659 & 299.90 & 100.66 & 99.51 & 99.58 & 92.80 & 93.12 & 100.10 \\
\hline & 11.74 & 13.73 & 12.40 & 14.41 & 11.11 & 11.13 & 11.53 & 12.43 & 13.45 & 13.31 & 13.23 & 13.63 & 12.34 & 12.39 & 12.85 & 13.67 & 13.58 & 13.74 & 11.70 & 10.72 & 13.53 & 12.47 & 12.24 & 12.38 & 14.06 \\
\hline
\end{tabular}

